\title{
Gene Expression in Chronic Fatigue Syndrome
}

\author{
Ekua W. Brenu1,2, Kevin J. Ashton², Gunn M. Atkinson², \\ Donald R. Staines ${ }^{1,3}$ and Sonya Marshall-Gradisnik ${ }^{1,2}$ \\ ${ }^{1}$ Faculty of Health Science and Medicine, \\ Population Health and Neuroimmunology Unit, Bond University, Queensland, \\ ${ }^{2}$ Faculty of Health Science and Medicine, Bond University, Queensland, \\ ${ }^{3}$ Gold Coast Public Health Unit, \\ Queensland Health Robina, \\ Australia
}

\section{Introduction}

Chronic Fatigue Syndrome (CFS) is a disorder of unknown origin likely affecting multiple physiological processes. CFS is often a diagnosis of exclusion following a history of 6 months or more where patients may experience partial to full recovery, relapse or a worsening in symptoms and hence deterioration in health (Brkic et al., 2011). The clinical manifestations include moderate to severe fatigue, muscle pain, swollen lymph nodes, headaches, impaired sleep and cognition (Fukuda et al., 1994). A diagnosis of CFS is made using questionnaires which include Centre for Disease Prevention and control criteria for CFS, the Australian, British and Canadian CFS classifications and the recently developed World Health Organisation's International Classification of Diseases for CFS (Carruthers et al., 2011, Carruthers et al., 2003; Fukuda et al., 1994; Lloyd et al., 1990; Sharpe et al., 1991). CFS is a heterogeneous and multifactorial disorder. Mechanisms to explain the underlying factors and processes that are responsible for disease progression and symptom profile of this disorder remains to be established. However, research has demonstrated that CFS impacts the endocrine, neurological, immune and metabolic processes resulting in impaired physiological homeostasis (Brenu et al., 2010; Demitrack, 1997; Schwartz et al., 1994). While these processes are likely compromised and collectively contribute to ill health in CFS patients, CFS remains a disorder lacking a clear molecular or biochemical cause.

Twin studies have revealed that there is no single genetic factor associated with CFS (Evengard et al., 2005). Several molecular studies have identified genes that are differentially expressed in CFS patients in comparison to non-CFS individuals (Kaushik et al., 2005, Kerr et al., 2008; Gow et al., 2009; Light et al., 2009; Saiki et al., 2008). Additionally, these expressional differences in CFS may be as a result of the multifactorial nature of CFS. The challenge is to understand the relationship between these genetic discrepancies in CFS eventuating discovery of its pathomechanism leading to appropriate treatment and ultimately a cure. Gene expression studies in CFS have shown possible links between CFS and a number of molecular pathways associated with immune, neurological and metabolic processes (Kerr et al., 2008). The purpose of this chapter is to review the literature focusing on gene expression changes and their role in the pathophysiology of CFS. 


\section{Molecular studies}

\subsection{Candidate gene studies}

Candidate gene studies are mainly employed to address the biological characteristics of known genes that predispose them to have an involvement in CFS. The advantage of this approach is that it allows for the detection of common alleles with some effect on the disease presentation. Comparisons between CFS patients and non-fatigue controls on measures of allele and genotype frequencies of identified markers have shown significant differences between these groups. This method has been used to investigate the human leukocyte antigens (HLA) markers and killer cell immunoglobulin-like markers of NK receptors in CFS patients. In some CFS patients significant increases in HLA alleles, HLA-DQA1*01 and HLA-DQB1*06 have been observed compared to control participants (Smith et al. 2005). Among the killer cell immunoglobulin-like receptors (KIRs), high levels of KIR3DS1 with loss of HLA-Bw4lle80 ligands is common among CFS patients compared to control participants (Pasi et al., 2011). Similarly, other HLA haplotypes such as HLA-DRB1*1301 are elevated in CFS patients (Carlo-Stella et al., 2009). Polymorphisms in other receptors also occurs in CFS, importantly a number of the alleles for the receptor for advanced glycation end product (RAGE) may be decreased in CFS patients (Carlo-Stella et al., 2009). These changes in allelic frequencies and haplotypes especially in the HLA molecules may be associated with the inflammatory state of CFS patients.

Gene studies with SNPs may be an alternative pathway for determining susceptibility to CFS. CFS patients are more likely to have SNP variations for the glucocorticoid receptor gene NR3C1 with high incidence of risk conferring haplotypes (Rajeevan et al., 2007). The serotonergic system in some CFS patients is compromised and this is typified by an over active 5-hydroxytryptamine (5-HT) and a down regulated hypothalamic-pituitary-adrenal (HPA) axis (Demitrack, 1997). This likely occurs as a consequence of polymorphisms in genes that regulate serotonergic signalling. Hence, in CFS an increase in the polymorphism of the A allele linked with $-1438 \mathrm{G} / \mathrm{A}$ in the HTR2A receptor may explain these compromises (Smith et al., 2008). In particular, -1438G/A has been associated with suicide and cognitive impairment (Arango et al., 2003; Reynolds et al., 2006).

\subsection{Twin studies}

CFS may be prevalent in some families, thus, CFS may have a heritable component. However, the credibility of this observation remains to be determined. Self report measures and restriction fragment length polymorphism are most often used to assess the hereditability of CFS (Crawley \& Smith 2007). CFS may have a familial predisposition as relatives of patients with CFS may not necessarily meet the criteria for CFS but may be more prone to experience some of the symptoms of CFS (Walsh et al., 2001). Although twin studies allude to the existence of a genetic predisposition to CFS, this may be higher among monozygotic twins compared to dizygotic twins (Buchwald et al., 2001). Twins with CFS may share similar symptoms and experience the same level of severity in CFS related symptoms (Claypoole et al., 2007). Despite these heritable predispositions observed in twin studies, they are not enough to confirm a genetic basis for CFS (Albright et al., 2011). 


\subsection{Gene expression microarray studies}

Genome wide studies using microarrays is a predictive method of determining genes that may influence unexplained disorders such as CFS for which an aetiological mechanism is lacking. These large scale explorative studies are more often extensive and are able to determine the expression levels of genes expressed in CFS and non-CFS participants. While the results from these studies may be useful, validation through real-time quantitative polymerase chain reaction is most often required to ensure that the identified genes are representative of either a down or an up-regulation in gene expression patterns. Most of these large scale studies have identified genes that are differentially expressed in CFS compared to non-fatigued participants (Cameron et al., 2007; Carmel et al., 2006; Fang et al., 2006; Kaushik et al., 2005; Kerr et al., 2008; Saiki et al., 2008; Whistler et al., 2005; Whistler et al., 2003). In general, these genes regulate important physiological activities that are compromised in CFS. These include immune, endocrine, neurologic, metabolic and cellular activities. Elucidation of genes that predispose an individual to CFS is essential in understanding the mechanism of CFS. Gene expression studies have allowed for the identification of a number of genes involved in different aspects of the disease.

\subsection{CFS gene expression studies}

Many factors can influence susceptibility to CFS. Changes in the expression of genes important for various physiological processes may affect normal function. The vast majority of research in CFS has confirmed significant compromise to immune, endocrine, neurological and metabolic processes. Immunological abnormalities observed in CFS patients include decreases in cytotoxic activity of Natural Killer (NK) cells and perturbations in cytokine levels.

\subsubsection{Cytokine and chemokine genes}

Cytokines and their genes are vital for sustaining and regulating innate and adaptive immune activities such as cell differentiation, proliferation and activation. IL- 8 is a proinflammatory chemokine gene with chemotactic properties for neutrophils during pathogen invasion and other immunological insults (Huber et al., 1991). In CFS IL-8 has been shown to be significantly increased in expression in comparison to non-CFS individuals (Vernon et al., 2002). During neutrophil pathogen lysis, phagocytic products are released which acts as a positive feedback process to activate IL-8 to recruit more neutrophils (Ito et al., 2004; Sparkman and Boggaram, 2004). Alterations in $I L-8$ mRNA expression is linked with inflammation (Mukaida, 2003; Nozell et al., 2006; Xie, 2001). An increase in IL-8 expression noted in CFS patients may occur as a result of an increase in oxidative stress during inflammation (Shono et al., 1996; Ito et al., 2004; Sparkman and Boggaram, 2004). The promoter region of $I L-8$ is bound and activated by transcription factors including NF-KB A substantial decrease in the expression of $N F-\kappa B$ negatively affects $I L-8$ (Huang et al., 2001). $N F-\kappa B$ is a necessary component in the activation and signalling pathway of other leukocyte cytokines and reductions in their expression increases vulnerability to infectious agents and inflammatory reactions (Artis et al., 2003; Bohuslav et al., 1998; Sha et al., 1995; Campbell et al., 2000; Yang et al., 1998). 
During inflammation, immune cells such as macrophages produce pro-inflammatory molecules such as TNF- $a$. The severity of the inflammatory response determines the level of TNF-a produced. The TNFA gene is contained within the MHC complex; once it has been translated it functions by binding to TNF receptors TNFR1 or TNFR2. TNF- $a$ has a higher affinity for the TNFR2 receptor compared to the TNFR1 (Orlinick and Chao, 1998). TNFR2 modulates the proliferation of $\mathrm{T}$ lymphocytes and encourages pro-inflammatory responses. Usually a low concentration of TNF-a is required to activate TNFR2 while TNFR1 is stimulated in the presence of increased concentration of TNF-a. These interactions are vital for cell death signalling, cytotoxicity or cellular apoptosis (Zhou et al., 2002). TNFR1 and TNFR2 compete for TNF-a (Bodmer et al., 2002). TNFA is instrumental in controlling and regulating viral infection, NF- $\mathrm{KB}$ signalling, neuropathic pain and cytokines (Lee et al., 2009). In the central nervous system (CNS), glial-derived TNFA modulates synaptic plasticity by increasing the expression of $A M P A$ and also reducing long-term potentiation in the hippocampus (Leung and Cahill, 2010; Orlinick and Chao, 1998; Pickering et al., 2005). TNFA expression increases in the presence of stress and this has been observed in CFS patients although this increase was similar in healthy controls (Light et al., 2009). While mRNA levels in TNFA may be similar in CFS and healthy controls, polymorphism within TNFA may affect their ability to perform efficiently as shown in other diseases (Zhang et al., 2010).

IFNAR1 is required for IFNa/ $\beta$ antiviral responses and is therefore a key component in immunity against viral and bacterial infections (David, 2002). CFS patients are known to have significant increases in viral antigens and these may persist where the activities of IFNs are ineffective in inducing antiviral immune responses (Bansal et al., 2011). In CFS, IFNAR1 is increased in expression (Kerr et al., 2008) and this may occur as a result of persistent viral antigens or viral infected cells. It has been observed that IFNAR1 tends to increase in the presence of infections such as Human papillomavirus (HPV) and influenza (Gius et al., 2007; Jia et al., 2010). IL10-RA is both down- and up-regulated in CFS patients (Kaushik et al., 2005; Kerr et al., 2008). The protein, IL10-Ra is expressed on T cells, B cells, monocytes, macrophages, dendritic cells, NK cells, mast cells and microglia with no intrinsic kinase activity. Interactions between IL10-Ra and IL-10 stimulate the phosphorylation and activation of JAK1 and TYK2 kinases (Hebenstreit et al., 2005; O'Shea et al., 2002). This sequentially phosphorylates tyrosine residues in the cytoplasmic regions of IL-10Ra chains and forms docking sites for STAT3 (Moore et al., 2001). Janus Kinases and signal transducers and activators of transcription (JAK/STAT) pathways are essential for regulating cytokine mediated responses and vice versa (Schindler, 1999; Schindler et al., 2007). Genes such as STAT5A are induced by cytokines IL-2, IL-4 and IL-7. STAT5A is a critical element in the proliferation and survival of Th2 cells (Hebenstreit et al., 2005; Lin and Leonard, 2000). Differential expression in STAT5A in CFS likely affects the Th1-Th2 cytokine balance, possibly favouring an anti-inflammatory/Th1 like immune response, while suppressing pro-inflammatory immune reactions (Ihle, 2001; Kagami et al., 2001; Saiki et al., 2008; Skowera et al., 2004).

JAK1 contains cytoplasmic tyrosine kinases that react in a non-covalent manner to a varying number of cytokine receptors and is therefore implicated in lymphocyte development in particular, lymphocyte proliferation and differentiation (Flex et al., 2008). STAT5A and JAK1 are requisite for IL-2, IL-10, IL-7, IL-9, IL-13, IL-22 and IFN-a signalling (Schindler et al., 
2007). Hence, over expression of both STAT5A and JAK1 (Kerr et al., 2008; Saiki et al., 2008) may substantially alter the normal function of these cytokines and their receptors. These may include IFN-a, IL-7 and IL-10 (Kerr, 2008). Such adverse effects may cause shifts in the inflammatory profile causing either an increase or decrease in pro- and anti-inflammatory cytokines (Gupta et al., 1997; Vojdani et al., 1997). The exact profile of cytokines in CFS remains to be determined, although, a number of studies suggest that CFS is characterised by a predominant anti-inflammatory immune state (Skowera et al., 2004) others advocate a pro-inflammatory immune profile (Swanik et al.). This mixed picture suggests dysregulation of the balance in pro- and anti-inflammatory mechanisms.

Bidirectional communication between JAK/STAT signalling and cytokines is important for maintaining immune homeostasis. For example, IL-6 binds to its receptor and positively stimulates a number of JAKs and STATs which initiates a sequence of downstream effects that prompt the development and maturation of progenitor cells (Kamimura et al., 2003; Kristiansen and Mandrup-Poulsen, 2005). However, the expression of IL-6 can be dampened by suppressors of cytokine signalling (SOCS), this inevitably increases inflammation (Croker et al., 2003; Zhang et al., 2008). Hence, differential expression in IL-6, IL6R and IL6ST (Kerr, 2008; Light et al., 2009) may have adverse consequences on the activity of IL-6 in both the innate and adaptive immune response. This may also affect JAK1 in CFS (Guschin et al., 1995). Therefore in CFS differential expression in cytokine, JAK and STAT genes may increase susceptibility to prolonged immune deterioration.

TNFRSF1A is the gene for pro-inflammatory tumour necrosis factor (TNF)-a receptor, which increases pro-inflammatory events and stimulates the generation of cytokines through the activation of NF-kB (Nowlan et al., 2006). TNFRSF1A is also involved in cell death pathways involving TNFR-associated factor (TRAF) domains (Baud and Karin, 2001). In some CFS patients, cell death is particularly increased in neutrophils in comparison to non-fatigued controls (Kennedy et al., 2004; See et al., 1998; Vojdani et al., 1997). NF-kB gene, NFKB1, is decreased in expression in some CFS patients. Decreases in both NFKB1 and TNFRSF1A in CFS may potentially affect the proliferation of cytokines and chemokines such as IL-8 (Kerr, 2008). Additionally, NF-kB is inhibited by NFKBIZ which is also down regulated in CFS (Kerr, 2008). In the immune system, NF-kB is activated in response to toll-like receptors (TLR) (Kitamura et al., 2000; Yamazaki et al., 2001) by TRAF3 (Hauer et al., 2005; He et al., 2007; He et al., 2006). TRAF3 is instrumental in $\mathrm{T}$ cell related immune responses (Goldfeld et al., 1991). TRAF3 and NFKBIZ are collectively involved in the downstream activities of TNFRSF1A and NF-KB. Modifications in these genes can affect other cytokine pathways.

Another important gene, HIF1A, which encodes for the hypoxia induced transcription factor HIF1a, is responsible for the induction of apoptosis and inhibition of cell proliferation (Akakura et al., 2001; Carmeliet and Tessier-Lavigne, 2005; Yu et al., 2004). HIF1A also regulates pathogen lysis or phagocytosis mediated by neutrophils and macrophage (Nizet and Johnson, 2009). Oxidative phosphorylation is an important component of the phagolytic mechanism. This is deficient in some CFS cases and may cause a decrease in the amount of reactive oxygen species released from neutrophils to effectively breakdown the phagocytosed pathogen (Brenu et al. 2010). Impairments in oxidative phosphorylation in CFS patients may ensue from a downregulation in HIF1A. 
As previously mentioned, chemokines such as IL-8 are important soluble proteins that are necessary for immune cell trafficking during infection and other inflammatory insults. Chemokines such as CXCR4 are expressed by neutrophils, monocytes and T lymphocytes and their activities are regulated by cAMP, IL-6, IL-4, IL-10 and reactive oxygen species (Jazin et al., 1997). CXCR4 is necessary for hematopoietic cell trafficking, differentiation, endothelial migration and cell proliferation in the CNS and immune systems (Jazin et al., 1997; Moepps et al., 1997; Zou et al., 1998). CXCR4 is another gene involved in the identification of microbial factors such as LPS. The CXCR4 protein is part of the seven transmembrane G-protein super family of receptors (Pierce et al., 2002). CXCR4 promotes the proliferation of tumour cells via the MAP/ERK pathway and can in some cases have antiapoptotic properties (Darash-Yahana et al., 2004). Similar to the TLR4 and CD14 in response to LPS, CXCR4 expression becomes upregulated (Moriuchi et al., 1998). As these genes were simultaneously measured in the same CFS population, it is possible to posit that in some cases of CFS there are high levels of LPS factors, in particular LPS factors that cause heightened persistent immune activation. In these individuals perhaps these immune activations are not cleared and therefore encourage the survival of these microbial pathogens in circulation for a longer duration. In some CFS patients, CXCR4 is upregulated (Gow et al., 2009; Kerr, 2008) which may suggest an altered chemokine profile in CFS patients. Other genes such as CD47 are present on cells in the CNS and immune system. CD47 is a necessary factor in the migration of neutrophils and other cells (Brown et al., 1990; Gao et al., 1996; Lindberg et al., 1993; Parkos et al., 1996). It is also important in T cell activation and neurological function such as memory (Ticchioni et al., 1997; Waclavicek et al., 1997). In CFS, lymphocyte numbers in circulation may vary from patient to patient, however, the available number of lymphocytes at sites of infection or engaged in eliminating infected cells is not known. Incidentally, an upregulation in chemokine genes IL8, CXCR4 and CD47 may affect the efficiency of these cells to migrate to areas of infection (Gow et al., 2009; Kerr, 2008).

As previously discussed TGF- $\beta 1$ is an important pleiotropic cytokine as it regulates peripheral tolerance mechanisms in response to injury, cell growth and survival (Marie et al., 2005). TGF- $\beta 1$ is a critical component of the Treg differentiation pathway in particular Treg survival and FOXP3 expression (Marie et al., 2005). TGF- $\beta 1$ is also an important factor in cellular apoptosis involving Fas mediated apoptotic pathways and oxidative phosphorylation (Sanchez-Capelo, 2005). An upregulation in this gene may stimulate pathways that increase spontaneous apoptosis in neutrophils (Kennedy et al., 2004) and thereby prevent the induction of oxidative stress in CFS individuals (Brenu et al., 2010).

\subsubsection{Genes involved in pathogen lysis}

An important mechanism employed by both $\mathrm{NK}$ and $\mathrm{CD} 8^{+} \mathrm{T}$ cells to lyse viral pathogens is cytotoxic activity. The end result of cytotoxicity is cell death or apoptosis. Cytotoxic activity is achieved when the $\mathrm{NK}$ or $\mathrm{CD} 8{ }^{+} \mathrm{T}$ cells release lytic granules containing granzymes and perforin into the target cell through exocytosis (Leong \& Fehinger 2010). In the cell membrane of the infected cell perforin facilitates the binding of granzymes to different organelles of the cell and induce either caspase dependent or independent apoptosis (Pradelli et al., 2010). GZMA is the gene for granzyme A, it is essential for natural cytotoxic activity and antibody dependent cytotoxic activity of CD8 ${ }^{+} \mathrm{T}$ and NK cells via FC $\gamma$ RII (CD16) 
receptor (Lahmers et al., 2006; Madueno et al., 1993). GZMA induces slow apoptosis once released into the target cell. In some CFS patients mRNA levels for GZMA and GZMB are low while levels of perforin are increased (Brenu et al., 2010; Saiki et al., 008). Differential expression in these lytic molecules may explain the inefficiency of NK or CD8 ${ }^{+} \mathrm{T}$ cells in CFS patients to effectively execute cytotoxicity in the presence of pathogenic cells (Kilmas et al., 1990; Maher et al., 2005; Brenu et al., 2011).

However, discrepancies in the cathepsin C (CTSC) gene, which has wide distribution throughout the human body particularly in myeloid cells, polymorphonuclear leukocytes, alveolar macrophages and osteoclasts, can potentially affect the effectiveness of lytic cells (Hakeda and Kumegawa, 1991; McGuire et al., 1997; Rao et al., 1997b). Deficiencies in CTSC are associated with impaired activation of GZMA and GZMB in NK and cytotoxic T lymphocytes (Pham and Ley, 1999). This implies that CFS patients presenting with atypical CTSC expression may also exhibit decreased GZMA and GZMB production (Maher et al., 2005; Saiki et al., 2008). Cytotoxic activity may be considerably low as a consequence of low expression of granzyme genes in CFS patients, thus an increase in viral load will be highly detrimental to the compromised immune system.

\subsubsection{Transcription factors}

The regulation of genes is dependent on molecules known as transcription factors (Farnham, 2009). In CFS, transcription factor genes are differentially expressed. Among them is EGR3, which regulates lymphocyte proliferation, apoptosis and inflammatory responses (Beinke and Ley, 2004; Inoue et al., 2004; Jiang et al., 2005). EGR3 in T lymphocytes stimulates Fas-L formation and cytotoxic activity of CD8 ${ }^{+} \mathrm{T}$ lymphocytes (Matsuoka and Jeang, 2005). Their dysregulation affects the production of IL-2 (Safford et al., 2005), an important factor in anti-inflammatory Treg and Th2 differentiation. In CFS patients this may be associated with the deficits in cytotoxic activity and the presence of anti-inflammatory immune responses (Kerr et al., 2008).

TRAIL is another gene expressed by both innate and adaptive immune cells. It is important in inducing cellular apoptosis in immune cells, monocytes, dendritic cells, NK and CD8 ${ }^{+} \mathrm{T}$ lymphocytes (Schaefer et al., 2007). In cytotoxic cells such as NK and CD8+T, TRAIL serves as an alternative pathway for effective cytotoxic activity against viral antigens (Janssen et al., 2005; Kayagaki et al., 1999). Th2 cells preferentially express TRAIL and therefore are able to kill other immune cells and infected cells (Zhang et al., 2003). Hence, CFS patients with deficiencies in this gene may experience decreases in NK and CD8+T cell cytotoxic activity and induction of apoptosis, making them more vulnerable to immune infection and hindering normal immune function in these individuals.

NFATC1 is the gene for the nuclear factor of activated T lymphocytes belonging to the NFAT family of transcription factors. This transcription factor regulates genes encoding cytokines and cytokine receptors in response to antigen activation (Crabtree and Clipstone, 1994; Rao et al., 1997a). Importantly, they are implicated in T cell abundance, Th2 differentiation and cytokine production (Yoshida et al., 1998; Ranger et al., 1998). Impaired Th2 cytokines in some cases of CFS may emanate from perturbed expression in NFATC1. Conversely, other genes such as human $\beta$-defensin 1 (DEFB1) may have unfavourable consequences on the Th1 cytokines causing an over abundance of these proteins in some 
cases of CFS (Wehkamp et al., 2005). DEFB1 is involved in immunomodulation against microbial peptides in both the innate and adaptive immune response. Using the CCR6 receptor they are able attract dendritic cells and CD4+T lymphocytes (Yang et al., 1999) during infection and inflammation (Dommisch et al., 2005; Sun et al., 2005; Wehkamp et al., 2005). Animal models have confirmed that an increase in susceptibility to microbial infections infections ensues in the event where DEFB1 is deficient or mutated (Morrison et al., 2002; Moser et al., 2002). CFS related serological and virological studies indicate significant increases in viral antigens in some CFS patients and this may also be linked to defects in DEFB1.

ETS1 encodes for a transcription factor that binds to DNA sequences with an invariant GGA (Gegonne et al., 1993). ETS1 like many other transcription factors is upregulated in CFS patients (Kerr et al., 2008). ETS1 is an early response transcription factor gene with binding sites for transcription factors AP1, AP2 and ETS at its promoter end (Dittmer, 2003; Thomas et al., 1997). It is found in the nucleus where phosphorylation of Ras strongly increases transcriptional activity of ETS1 and its interactions with other proteins through the ETS1 domain (Wasylyk et al., 1998). ETS1 acts together with other genes to increase its function hence it is positively regulated by AML-1, Pit-1 and HIF-2a (Dittmer, 2003). ETS1 sequentially excites the DNA binding process of these genes. ETS1 can be inhibited by CAMKII, Daxx/EAPI and ZEB (Dittmer, 2003). ETS1 synergises with TGF- $\beta$ to activate other genes. Activated T cells usually have a decreased expression of ETS1 compared with dormant T cells T cells (Bhat et al., 1990). ETS1 is found in T, B, and NK cells. It is a protooncogenic transcription factor which is involved in naïve $\mathrm{T}$ cell development and differentiation (Di Santo, 2010). In T cells, deficiencies in ETS1 can inhibit T cell responses to other stimulatory signals and increase susceptibility to cell death. Although, ETS1 expression decreases in the activated $\mathrm{T}$ cells in the developing $\mathrm{T}$ cell it is essential in prompting the expression of TCRa and TCR $\beta$ (Giese et al., 1995). Additionally, ETS1 interacts with other immune regulators such as STAT5 which is implicated in $\mathrm{T}$ cell responses (Rameil et al., 2000). ETS1 is an essential gene necessary for the optimal optimal development of naïve $\mathrm{T}$ cells, an increase in this gene may suggest an increase in resting $\mathrm{T}$ cells over activated T cells in CFS patients. Although, increases in some subsets of $\mathrm{T}$ cells such as FOXP3 Tregs (Brenu et al., 2011b) have been suggested, it is possible that these cells are not adequately activated and a majority of these cells are in the resting phase it is most likely thus are not able to effectively clear infections or encourage most favourable immune profile in CFS patients. NK decrease in cytotoxic activity may also be related to ETS1 over expression as ETS1 is important in NK cell development (Yokoyama et al., 2003). Failure of NK cells to develop into efficient lytic cells can hinder their ability to recognise and eliminate pathogens. Loss of function in ETS1 impairs proper lymphocyte differentiation and permits autoimmune responses (Wang et al., 2005). However, FOXN1 is involved in the development and differentiation of thymic epithelial cells (TECs) (Su et al., 2003). The expression of FOXN1 is controlled by Bone Morphogenetic proteins (BMPs) and WNT (Coffer and Burgering, 2004). Immune deficiencies arise when mutations occur in FOXN1 (Coffer and Burgering, 2004). In CFS, FOXN1 has been suggested as a potential candidate gene for the development of biomarkers for CFS and may be linked to the severity of CFS (Presson et al., 2008). Abnormal changes in FOXN1 affects T cell development and function and may relate to the cytokine pattern in CFS. 
The histone acetyltransferase and deacetylase (HDAC7A) gene modulates nuclear histone acetylation. It inhibits the activity of myocyte enhancer-binding factor (MEF) and is highly expressed in thymocytes (Kasler and Verdin, 2007). This gene is responsible for transcriptional repression and the maintenance of cellular integrity (de Ruijter et al., 2003). It is an efficient co-repressor of the androgen receptor (AR) (Karvonen et al., 2006). It regulates apoptosis in developing thymocytes and may be associated with the decrease cytotoxic activity noticed in some CFS patients. Given that transcription factors are important in most cellular processes, a decrease or increase in its expression can have crucial consequences on the normal functioning of many physiological processes.

\subsubsection{Immune regulators}

The current data on CFS strongly support an impaired immune function characterised by differential expression of cytokines and decreases in cytotoxic activity. These observed immune defects may ensue from changes in the expression of certain genes involved in the signalling pathways of these immune indices. MAPK9 codes an important signalling molecule known as the JNK2 protein kinase and its disruption is associated with the pathogenesis of destructive insulitis (Jaeschke et al., 2005). Some microbes are able to downregulate MAPK9 which in turn inactivates JNK2 thereby decreasing transcriptional events in this pathway (Zhang et al., 2004).

The cytochrome P450 (CYPIBI) gene has a role in responding to environmental toxins and mutagenic products (Hayes et al., 1996; Shimada et al., 1996). Although it is expressed in higher concentrations in breast cancer (Huang et al., 1996), in CFS it most likely involved in increased susceptibility to toxic agents. As CFS is likely a multi-factorial disorder, prolonged exposure to toxic agents may predispose an individual to CFS. CMRF35/CD300C encodes the CD300c leukocyte surface protein present on macrophages (Turnbull and Colonna, 2007). Secretion of TNF- $\alpha$ and IFN-a is highly dependent on CYPIBI (Ju et al., 2008). Additionally, abnormalities in CFS cytokine profiles possibly occurs where CMRF35 is differentially expressed, distorting anti-viral (IFN- a) and pro-inflammatory (TNF- $\mathrm{a}$ ) activities required for maintaining immune homeostasis (Sen, 2001).

Adhesion molecules are important for interactions between $\mathrm{T}$ cells and other cellular surfaces. In T cells the adhesion molecule CD2 allows T cells to connect with other cells. CD2 is regulated by $C D 2 B P 2$ (the CD2 binding protein 2) which increases binding specificity of the cytoplasmic domain of the T cell adhesion molecule CD2 and localizes it to the cell membrane and nucleus. TLR4 is an anti-tumour repressor and which inhibits the destruction of tumour antigens in lysosomes of dendritic cells. This facilitates antigen presentation to T cells and enhances the binding of LPS to MD-2. TLR4 mediated signalling can either occur via MyD88 dependent or independent pathway. When the MyD88 dependent pathway is used, this leads to the production of pro-inflammatory cytokines while the MyD88-independent pathway induces Type I interferons and interferon inducible genes (Lu et al., 2008). Human macrophages express CD14, a glycosylphosphatidylinositollinked plasma-membrane glycoprotein, on their cell surfaces that facilitate the induction of apoptosis of foreign cells (Vita et al., 1997). CD14 in conjunction with TLR4 and MD2 initiates the formation of a lipopolysaccharide receptor complex that controls immune responses to pathogens in the respiratory system, recognition of LPS and the generation of systemic inflammation (Wright et al., 1990). An increased expression in both TLR4 and CD14 
may suggest an increase in LPS, LPS increases the expression of these genes (Foster et al., 2007). The biphasic expression of these genes allows them to have either an activating or a limiting effect on other genes. Additionally, in most cellular responses to bacterial infection due to LPS release, the MyD88-independent signalling pathway is activated. TLR4 may bind to the cell membrane allowing efficient presentation of LPS to TLR4. It is evident that modulation of the expression of CD14 and TLR4 can have severe consequences on the ability of immune cells to recognise microbial particles. Nonetheless, these observations are indicative of a heightened immune activation as a possible contributory factor to the compromised immune function in CFS patients.

Other neutrophil related genes have also been suggested to be differentially expressed in CFS patients. Genes such as SNAP23 (Synaptosomal-associated protein 23) and CFACAM8 are upregulated in some cases of CFS (Gow et al., 2009; Kerr et al., 2008). SNAP23 is present mostly in non-neuronal tissues and is part of the t-SNARE complex (Washbourne et al., 2002). SNAP23 controls neutrophil exocytosis and also cell surface granule interactions and is thus essential for intracellular trafficking of vesicles/granules (Lacy, 2006; Zylbersztejn and Galli, 2011). CFACAM8 on the other hand is important in cell adhesion, migration and signal transduction in neutrophils (Zhao et al., 2004). These genes are therefore essential for the movement of neutrophils to sites of inflammation and or infection.

\subsubsection{Other cellular processes}

Other genes examined in CFS are necessary for many cellular processes. These genes may be implicated in functional properties of cells in a number of physiological processes suggesting a heterogeneous clinical presentation. For example, ARPC5 is the smallest subunit of the actin related protein complex 5, which controls the polymerization of actin (Pollard, 2007). This normally occurs in response to cellular motility during the polymerization of new actin filament. Dendritic cells have not being adequately investigated in CFS, however, their morphogenesis may be compromised as evident by the over expression of ANAPC11 (Gumy et al., 2011). ANAPC11, anaphase promoting complex subunit 11, has a role in dendritic cell morphogenesis (Domingo-Gil et al., 2010). It is part of a complex that targets and degrades proteins during mitosis. The migration of cells from one point to another, in circulation, involves the interplay of a number of genes such as ATP5J2, an ATP synthase involved in cellular processes requiring ATP (Cheung and Spielman, 2009). APP, the amyloid precursor gene is a marker for Alzheimer's disease (Zetterberg et al., 2010). It regulates cell surface proteins (Hoe and Rebeck, 2008).GSN is an anti-apoptotic regulator, and an actin serving protein that modulates actin assembly, disassembly and regulates cell motility via the actin network (Hoe and Rebeck, 2008). REPIN1 is highly expressed in the liver and adipose tissue. It is a replication initiator and is involved in a number of metabolic disorders (Bahr et al., 2011).

A number of genes identified in CFS patients are involved in metabolic pathways specifically the protein kinases, ATP and cAMP related genes. These genes interact to maintain normal metabolic activity. These include transmembrane protein 50A (TMEM50A) located in RH gene locus, ATP6V1C1 which regulates extracellular acidification to facilitate bone resorption (Feng et al., 2009) and PRKAR1A inhibits protein phosphorylation and tumour development (Bossis and Stratakis, 2004; Groussin et al., 2002). Mutations in PRKAR1A have been associated with tumour development (Scott, 1991; Tasken et al., 1997). 
AKAP10 is the kinase-anchoring gene 10 which is currently an identifier for determining the risk of developing colorectal cancer (Wang et al., 2009a; Wang et al., 2009b). It also requires cAMP to diffuse through the cytoplasm to propagate its signal. AKAP10 modulates immune responses related to PGE2/EP2/CAMP/PKA pathway (Kim et al., 2011). It targets regulatory subunit of PKA to specific cell sites such as the mitochondria. The cAMP responsive element binding protein (CITED2) refers to ( $\mathrm{Xu}$ et al., 2007). It modulates hypoxia inducible factor dependent expression of vascular endothelial growth factor and hematopoietic stem cells. In CFS, we have recently reported an increase in neuropeptide receptors, specifically in VPACR2 in a cohort of CFS patients (Brenu et al., 2011b). This increase in VPAC2R may translate into an increase in cAMP causing a potential increase in PKA activity in CFS. An increase in cAMP may increase the expression of PKAR1A, AKAP10 and CITED2 and hence making their regulatory effects redundant and altering the physiological homeostasis. Tyrosine kinase non-receptor 2 (TNK2) functions as a translational repressor during cell fate specification and is necessary for the expression of epidermal growth factor receptors (Howlin et al., 2008).

Mitochondria related genes are also differentially expressed in CFS these genes include SUCLA2, MRRF, EIF4G1, MRPL23, GABPA, PRDX3 and EIF3S8. As cellular function is impaired in CFS it is likely that important organelles especially those related to metabolic processing may be functioning at suboptimal levels. SUCLA2is involved in mitochondria regulation (Miller et al., 2011), EIF4G1 is an initiation factor implicated in mitochondrial induced apoptosis (Bushell et al., 2000), MRRF regulates cell survival (Rorbach et al., 2008) while PRDX3 prevents oxidative damage to cells (Ejima et al., 2000). Additionally, GABPA, EIF3S8 and MRPL23 have broad functions in mitochondria (Wyrwicz et al., 2007; Zhang and Wong-Riley, 2000). Mitochondria in the muscles of patients with CFS produce relatively low energy when compared to non-fatigued controls (Plioplys and Plioplys, 1995). In some cases patients may present with structural deformities in the mitochondria, these include subsarcolemmal mitochondrial aggregates, compartmentalization of the internal mitochondrial membrane and polymorphism (Plioplys and Plioplys, 1995). Similarly defective mitochondrial metabolic activity may be characterised by the presence of neurotoxic phospholipids and phospholipids of mitochondria that appear after microbial infections (Hokama et al., 2008). Neutrophil in the innate immune system employ respiratory burst and oxidative phosphorylation as a means to effectively kill and clear pathogen invasion. This unique mechanism is advantageous and reduces the persistence of microbial infections. Respiratory burst in CFS is flawed. The authors have previously shown that in CFS neutrophils are able to recognise and engulf pathogens however, the ability to induce and activate reactive oxygen species to induce respiratory burst is significantly compromised when compared to non-fatigued controls (Brenu et al., 2010). Incidentally, abnormal mitochondrial function exists in CFS where ATP and oxidative phosphorylation is substantially lower in the CFS patients (Myhill et al., 2009).

\subsubsection{Neurology and endocrine function}

Neurological dysfunction in CFS may present in many formats, the most obvious documented symptoms are loss in memory and concentration, sleep disorder and severe headaches. While the exact cause of CFS remains to be determined it has been postulated that neuroimmune abnormalities in form of dysregulation in cytokines due to a prevalent 
viral antigens in the brain may enhance CFS related neurological deficits (Kuratsune et al., 2001). In CFS a number of genes that regulate neurological and endocrine function have also being detected to be equivocally expressed when compared to non-fatigued controls. These observations may relate to the impairment in cognition and other neurological functions associated with this disease. The HPA axis is distorted in CFS and this may have a bearing on the changes in other genes (Ursini et al., 2010). EIF2B4 affects neurological function and has been shown to be related to mitochondrial function. It refers to the eukaryotic translation factor 2B subunit 4. It has been implicated in Vanishing White Matter disease (VWM). Although CFS is not an inherited disorder it may share similar symptoms with VWM. Both CFS and VWM are associated with infections (Bansal et al., 2011). CFS patients and patients with VWM may demonstrate abnormalities in cerebrospinal fluid (Schutzer et al., 2011a; Schutzer et al., 2011b). White matter studies in CFS are inconsistent, in some instances, abnormal white matter has been observed (Lange et al., 1999; Schwartz et al., 1994). Also, grey matter in some CFS patients may be reduced (de Lange et al., 2005). These confounding factors may to some extent relate to the severity of neurological impairments in patients with CFS.

NHLH1 is the helix-loop-helix transcription factor whose expression is restricted to the nervous system. It is important during development and neuronal differentiation (De Smaele et al., 2008). In mice loss of NHLH1 generates irregular autonomic function characterised by arrhythmia, dampening of parasympathetic and in increase in death (Cogliati et al., 2002). A number of CFS patients may present with a dysfunctional autonomic system which may be related to an increase in heart rate and a decrease in systolic blood pressure. Additionally, irregularities in $\mathrm{pH}$ and heart rate variability occur in CFS patients following exercise (Jones et al., 2009; Newton et al., 2007). SORL1 refers to the sortilin-related receptor. It is a neuronal sorting protein-related receptor that is involved in intracellular trafficking. It directs trafficking of amyloid precursor protein and is decreased in the brains of humans suffering with Alzheimer's disease (Shibata et al., 2008). It is associated with risk of late onset of AD. This gene may be partially responsible for the memory loss experience by some CFS patients although this needs further clarification (Reynolds et al., 2010). PKN1 is part of the neurofilament head rod domain kinase. It is a serine/threonine protein kinase that mediates cellular response to stress (Kato et al., 2008). $P K N 1$ regulates gene expression in response to extra cellular stimuli. Overexpression of PKN1 causes a substantial elevation in the phosphorylation of ERK (Kajimoto et al., 2011). A number of CFS patients show an upregulation in genes in the ERK signalling pathway when compared to non-fatigue controls (Kerr et al., 2008). Phosphorylation of TRAF1 is dependent on PNK1 and this also regulates the ratio of TRAF1 and TRAF2 and determines the NF-K $\beta$ and JNK signalling (Kat et al., 2008). TRAF1 and TRAF2 in turn modulate the signalling activity of IKK and JNK (Gotoh et al., 2004). An upregulation in PKN1 may severely alter the downstream signalling pathways associated with PKN1. Importantly NF-k $\beta$ immune related activities maybe distorted where PKN1 is upregulated. NF- $\kappa \beta$ regulates inflammatory cytokines (Park and Levitt, 1993). In CFS alterations in cytokine distribution has been observed. This may be either towards a pro- or anti-inflammatory cytokine profile. In the CNS system shifts in cytokine profiles have been reported for many autoimmune disorders and a similar mechanism may occur in CFS patients as a consequence of prevailing viral and microbial antigens that are not effectively cleared following infection. Perhaps these antigens remain and therefore modulate the cytokine milieu in the CNS. 
Additionally heightened pro-inflammatory mechanisms followed by an increase in suppression may exist in the CNS neuroimmune system in an attempt to dampen viral and microbial survival in the CNS.

During development, HOXA1 is expressed in the hindbrain (Studer et al., 1998). It is an essential developmental gene belonging to the homeobox genes. It is associated with autism. The product generated from translation of this gene is a transcription factor which is important in cell differentiation, embryogenesis, defining body plan during development and oncogenic transformation. Recently HOXA1 has been observed to be a target of miR-10a (Shen et al., 2009). COMT is the catechol-O-methyltransferase, it is critical for the metabolic degradation of dopamine (Blanchard et al., 2011). It is involved in the function of dopamine in the prefrontal cortex of the human brain thus it is involved in frontal lobe functioning (Meyer-Lindenberg et al., 2005). The inability of most CFS patients to concentrate for long periods on activities requiring higher order cognitive function may be explained by dysregulation in COMT.

\subsection{MicroRNA}

MicroRNAs (miRNA) are recently described, highly conserved molecules with regulatory activities in multi-cellular organisms such as mammals. They are small components of ribonucleoprotein particles belonging to a family of RNA which have diverse effects on physiological function. MicroRNAs are suppressors of gene expression and affect either translational processes or the stability of mRNAs through the encouragement of decay processes, deadenylation and decapping processes termed RNA interference (Mishima et al., 2006; $\mathrm{Wu}$ et al., 2006). The expression of the miRNA gene results in the creation of the primary transcript (pri-miRNA) that is $60-80$ nucleotides in length. This pri-miRNA contains a hairpin stem-loop structure which is cleaved by the enzyme Drosha (RNA III enzyme) and DGCR8 (DiGeorge critical region 8), resulting in the creation of a structure comprised of a $\sim 22$ base pair stem, 2-nucleotide 3' overhang and a loop, collectively known as the precursor-miRNA (pre-miRNA) transcript (Lee et al., 2003). The pre-miRNA transcript is transported into the cytoplasm where RNase III enzyme, Dicer, cleaves the terminal loop of the pre-miRNA transcript to form a 18-24 base pair product (Lee et al., 2002). A currently unidentified helicase then produces individual miRNA strands - a mature miRNA, which is the mediator of mRNA repression, and the passenger strand, which is rapidly degraded. The mature miRNA is integrated into an RNA induced silencing complex (RISC) with Argonaute (Ago) proteins where it is further processed (Khvorova et al., 2003; Lee et al., 2003; Lingel et al., 2003; Mourelatos et al., 2002). The final product formed from this sequence of events is a miRNA-RISC complex. Suppressive effects of miRNA on mRNA molecules occur via the RISC complex in which Ago is able to exercise endonuclease activity on the double stranded miRNA-mRNA structure (Hutvagner and Zamore, 2002). The mature miRNA can bind to complete and incomplete complementary strands of mRNA molecules and degrade the mRNA or inhibit translation respectively (Behm-Ansmant et al., 2006; Hutvagner and Zamore, 2002; Lim et al., 2005). Through these mechanisms it has been extensively documented that miRNA regulates a diverse range of physiological activity and also contributes to disease states such as cancer (Lu et al., 2005) and cardiomyopathy (Chen et al., 2006). Interactions between the miRNA and mRNA molecules are important for maintaining physiological processes in development and homeostasis and have already 
been associated with numerous disease states. However, the role of miRNA in CFS is largely unknown. For further reading on the cellular and physiological processes of miRNA, the reader is directed to Sun et al. (2010).

With consistent trends between immunological dysfunction and CFS becoming more apparent, miRNAs related to immune function are relevant to this understudied area and may hold potential for treatment. The first study of its kind to assess miRNA expression in CFS investigated the expression of miRNAs relating to immune function, apoptosis and cell cycle regulation (Brenu et al., 2011a). This study identified a general down regulation in most of the miRNA transcripts in NK cells of CFS patients. This supports the observation of immune dysregulation in CFS patients (Brenu et al., 2010; Maher et al., 2005), however, whether this is linked to a decrease in miRNA processing activity or is specific to miRNA function is yet to be determined. More specifically, this study found decreases in miRNA transcripts that are involved in apoptosis. CFS patients have been shown to demonstrate significant decrease in cytotoxic activity of NK cells hence decreases in miRNAs may contribute to the pattern of NK cytotoxicity noticed in CFS patients. For example, miR-146, which mediates the expression of NFK- $\beta$ and thus the transcription of numerous inflammatory mediators, was significantly decreased in CFS (Brenu et al., 2011b). The consequence of this may be a decrease in the cytokine secretion by NK cells as NFK- $\beta$ is an important regulator of cytokine production in these cells (Gerondakis \& Siebenlist 2010). Incidentally IFN- $\gamma$ was noticed to be significantly decreased in expression in the same cohort of CFS patients with a decrease in miR-146 (Brenu et al., 2011b). Similarly, in the presence of an altered NFKB expression, NK responsiveness to IL-12 in CFS patients may be dampened compromising immune response to both infection and homeostasis (Broderick et al., 2010). Further studies are needed to verify whether miRNAs contribute or are linked to depressions in IL-8, IL-13 and IL-5 and increased activity of IL-1a, IL-1 $\beta$, IL-4, IL-5, IL-6 and IL-12 in CFS patients (Fletcher et al., 2009). Substantial decreases in the expression miR-21 were observed in the CFS patient group. These results suggest the presence of a possible compromise in the maturation and function of lymphocyte translating into decreases in cytotoxic activity (Salaun et al., 2011). Direct evidence of this however, remains to be established.

At the present miRNA research is at its infancy hence the exact role of miRNAs in NK cells is subject to speculation. Similarly the gene expression miRNA studies in CFS is severely lacking therefore only postulations can be made about the link between the miRNAs and the disease. However, the promising data shown in the aforementioned studies likely suggest that miRNAs may indeed play greater roles in the dysregulation of immune function in CFS.

MicroRNAs may regulate other aspects of immune function in CFS, the above mentioned study is limited as it only examines NK and CD8 ${ }^{+} \mathrm{T}$ cells. However miRNAs are known to regulate most if not all immune cells. In the innate immune system, miRNAs such as miR-155 enhance the maturation of macrophages and dendritic cells via the TLR receptor pathway, causing heightened sensitivity in these cells to antigens in circulation (O'Connell et al., 2007; Tili et al., 2007). CD4 ${ }^{+} \mathrm{T}$ cell matuation into various subsets in the periphery is regulated by miRNAs (Wu et al., 2007). The generation of Tregs that express FOXP3 is to some extent dependent on miRNAs (Kohlhaas et al., 2009). Any perturbed effects in miRNAs can influence thymic and peripheral derived Tregs especially in response to TGF- $\beta$ stimulation on naive 
$\mathrm{CD}^{+} \mathrm{T}$ lymphocytes (Ha, 2011). Modulation of the effects of these molecules is essential for appropriate immune response to bacterial and viral invasion and current studies show these areas may be impaired in CFS sufferers. Importantly, deficiencies in components of the miRNA such as Dicer promotes a predominant Th1 response governed by IFN- $\gamma$ with a reduction in the effects of Th2 cells and Treg cells (Cobb et al., 2006). In contrast a predominant Th2 $\mathrm{CD}^{+} \mathrm{T}$ cell profile prompting systemic inflammation emanates from deficiencies in the miR-155 (Rodriguez et al., 2007; Thai et al., 2007) while in the absence of miR-101, autoreactive $\mathrm{T}$ cell mediated autoimmunity occurs (Yu et al., 2007). In CFS there are inconsistencies in the data on Th1/Th2 profiles. It is likely that in the event that immune related miRNAs are differentially expressed, shifts in Th1 and Th2 inflammatory response and defects in TLR signalling may occur, and this may be related to the pathophysiology of CFS. Whilst it is believed that many miRNAs are yet to be discovered, evidence is scarce to describe the multitude of various physiological roles of currently discovered miRNAs. Despite this, the current evidence that links miRNA dysregulation to the characteristics of CFS has shown that there is merit in the roles of miRNA in CFS. Further advancements are needed to characterise the role of miRNAs in CFS.

Our current investigative techniques for identifying transcriptional changes in known miRNAs are quickly advancing through microarray technology. This method uses the same principle as DNA microarray technology and allows for semi-quantitative expression changes of a large number of miRNAs in a single chip (Li and Ruan, 2009). The clear advantages of using microarray is the high throughput and vast number of transcripts analysed in a single chip as compared to low throughput and tedious methods of microRNA cloning, northern blotting and real time RT-qPCR. As mentioned in section 2.2, this gives investigators the power to identify expression differentials in gene categories, allowing the association of a particular state or disease to a molecular or physiological category. Numerous limitations are associated with microarray technology, most importantly is the ability to identify changes in already known miRNAs, as the targets require hybridisation with specifically designed probes attached to the chip. Moreover, these expression changes are only semi-quantitative due to the hybridisation techniques used, resulting in a lack of reproducibility. These pitfalls are similar to those in DNA microarray but are likely not as pronounced due to the various isoforms and large size of genes as compared with miRNAs (Fathallah-Shaykh, 2005). Finally, microarray technology has the disadvantage of only being able to detect known transcripts. With possibly many undiscovered transcripts this poses a problem for miRNA discovery in differential expression using this method and may also interfere with target specificity. However, more recent investigative techniques look promising for the discovery of new target miRNAs as well as addressing many of the pitfalls of the low-throughput and microarray based methods. One such example is sequence-by-synthesis technology, which has recently been used with investigative application and is likely to be used more widely in the near future (Morin et al., 2008).

\subsection{MicroRNA-based gene therapy}

The roles of microRNAs in diseases are likely to become targets for therapy. The current experimental practice is known as gene silencing and the specialised transcripts used in such instances are known as small interfering RNA (siRNA) (Wang et al., 2011). The cellular method of translation or transcription repression is the same as miRNAs - through the use of RISC, however in gene silencing the target-specific substrate, the siRNA, is exogenously 
introduced. There is currently little in the way of clinically translated practice of gene therapy using the siRNA method, as it is associated with a number of problems. The most notable of these is delivery and cell specific targeting. The current means of delivery in experimental models is via adeno- or adeno-associated virus constructs transcribing the specific siRNA or siRNAs of choice. To allow for cell specific targeting certain virus constructs are suited for various cell types however the lack of specificity and low percentage uptake makes this is an improbable method of therapy at present. There are however new experimental means of delivery currently being optimised (Yuan et al., 2011). Once such issues have been addressed the significance of gene silencing may be relevant in CFS. With increasing amounts of evidence indicating that CFS likely has a strong molecular basis, such methods hold merit once initial targets have been discovered. The current stance on miRNAs in CFS calls for further research in the area in both genome wide miRNA analysis in longitudinal studies, and also the search for new miRNAs possibly implicated in this disorder. With the current technology available, and promising experimental therapeutics such as gene silencing, miRNA is likely to play a large and significant role in possibly the development of biomarkers, mechanisms or treatment of CFS.

\subsection{Future directions}

The high variability in genomic anomalies within CFS patients may be an underlying cause of our current inability to effectively treat the disorder. No specific conditioning or dieting routine has proven beneficial for a wide majority of patients and even more elusive are effective pharmacological targets for this population. It is probable that various underlying mechanisms may give rise to the variable patient-described symptoms of CFS. This may explain the lack of efficient treatment options and opens questions in the area of pharmacogenomics. Pharmacological agents specific to genetic traits that are associated with CFS and possibly subsets of the disease may be useful in monitoring CFS. In the context of CFS, this pertains to our lack of understanding and inability to define areas of treatment, suggesting that a suitable treatment may call for the definition of subtypes of the disease or populations that are genetically predisposed to such symptoms.

However, at present the most important aim of research worldwide is to establish biomarkers for CFS. Currently the most stable and reliable marker is NK cytotoxic activity (Brenu et al., 2011b; Fletcher et al., 2009; Klimas et al., 1990; Maher et al., 2005). Consistent data worldwide suggest that a decrease in cytotoxic activity is a hallmark of CFS. In most cases this decrease has been associated with differential expression in cytotoxic molecules including GZMA, GZMK, GZMB and PRF1 (Brenu et al., 2011b; Saiki et al., 2008). Developing pharmacological agents that specifically target these cytotoxic genes in order to increase or decrease their expression might be an alternative method of treating impaired cytotoxic activity in CFS patients. Subtypes of CFS patients may exist and this may be based on clusters of symptoms or severity of illness. Hence these may need to be considered when developing appropriate agents for modulating the disease.

\section{Conclusion}

In summary, the repercussions of these changes gene expresseion may contribute tremendously to the disease profile of CFS. The genes discussed above have vital roles in most immune related activities such as inflammatory modulation, lymphocyte and cytokine 
activation, lymphocyte differentiation and proliferation and are also implicated in the apoptosis signalling pathways. Hence, an up-regulation in chemokine genes may affect leukocyte response to infection and other immunological insults while down-regulation in pro-inflammatory cytokine genes may disrupt inflammatory reactions. Importantly, the consistent observation of impaired NK cytolysis in CFS is partly due to the reduced expression of perforin and granzymes genes. As previously discussed these granzymes induce apoptosis of antigens within the cell. Variation in cytokine release and production can be explained by the altered levels of pro- and anti-inflammatory cytokines. Most of these cytokines are engaged in other physiological processes. Hence, defects in their production can severely hinder physiological function and homeostasis. Other symptoms such as cognitive impairment and changes in the HPA axis in CFS patients may emanate from an increase NHLH1 while changes in mitochondria genes contribute to fatigue and muscle weakness. Although, these studies have to some extent provided information on the genetics of CFS patients, it is not known whether CFS elicits these changes in gene expression patterns or vice versa. Similarly, most of the genes observed in these studies have not been replicated in other CFS patients. It is therefore very difficult to ascertain which specific cells are compromised among the CFS population. Further studies are now required to determine how changes in gene expression can be related to the mechanism of CFS and the specific cells or systems that may be severely compromised in this disorder.

\section{References}

Akakura, N., Kobayashi, M., Horiuchi, I., Suzuki, A., Wang, J., Chen, J., Niizeki, H., Kawamura, K., Hosokawa, M. and Asaka, M. (2001) Constitutive expression of hypoxia-inducible factor-1alpha renders pancreatic cancer cells resistant to apoptosis induced by hypoxia and nutrient deprivation. Cancer Res 61, 6548-54.

Albright, F., Light, K., Light, A., Bateman, L. and Cannon-Albright, L.A. (2011) Evidence for a heritable predisposition to Chronic Fatigue Syndrome. BMC Neurol 11, 62.

Arango, V., Huang, Y.Y., Underwood, M.D. and Mann, J.J. (2003) Genetics of the serotonergic system in suicidal behavior. Journal of psychiatric research 37, 375-86.

Artis, D., Speirs, K., Joyce, K., Goldschmidt, M., Caamano, J., Hunter, C.A. and Scott, P. (2003) NF-kappa B1 is required for optimal CD4 $4^{+}$Th1 cell development and resistance to Leishmania major. J Immunol 170, 1995-2003.

Bahr, J., Kloting, N., Kloting, I. and Follak, N. (2011) Gene expression profiling supports the role of Repin1 in the pathophysiology of metabolic syndrome. Endocrine.

Bansal, A.S., Bradley, A.S., Bishop, K.N., Kiani-Alikhan, S. and Ford, B. (2011) Chronic fatigue syndrome, the immune system and viral infection. Brain Behav Immun.

Baud, V. and Karin, M. (2001) Signal transduction by tumor necrosis factor and its relatives. Trends Cell Biol 11, 372-7.

Behm-Ansmant, I., Rehwinkel, J. and Izaurralde, E. (2006) MicroRNAs silence gene expression by repressing protein expression and/or by promoting mRNA decay. Cold Spring Harb Symp Quant Biol 71, 523-30.

Beinke, S. and Ley, S.C. (2004) Functions of NF-kappaB1 and NF-kappaB2 in immune cell biology. The Biochemical journal 382, 393-409.

Bellone, G., Aste-Amezaga, M., Trinchieri, G. and Rodeck, U. (1995) Regulation of NK cell functions by TGF-beta 1. J Immunol 155, 1066-73. 
Bhat, N.K., Thompson, C.B., Lindsten, T., June, C.H., Fujiwara, S., Koizumi, S., Fisher, R.J. and Papas, T.S. (1990) Reciprocal expression of human ETS1 and ETS2 genes during T-cell activation: regulatory role for the protooncogene ETS1. Proc Natl Acad Sci U S A 87, 3723-7.

Blanchard, M.M., Chamberlain, S.R., Roiser, J., Robbins, T.W. and Muller, U. (2011) Effects of two dopamine-modulating genes (DAT1 9/10 and COMT Val/Met) on n-back working memory performance in healthy volunteers. Psychol Med 41, 611-8.

Bodmer, J.L., Schneider, P. and Tschopp, J. (2002) The molecular architecture of the TNF superfamily. Trends Biochem Sci 27, 19-26.

Bohuslav, J., Kravchenko, V.V., Parry, G.C., Erlich, J.H., Gerondakis, S., Mackman, N. and Ulevitch, R.J. (1998) Regulation of an essential innate immune response by the p50 subunit of NF-kappaB. J Clin Invest 102, 1645-52.

Bossis, I. and Stratakis, C.A. (2004) Minireview: PRKAR1A: normal and abnormal functions. Endocrinology 145, 5452-8.

Brenu, E.W., Ashton, K.J., van Driel, M., Staines, D.R., Peterson, D., Atkinson, G.M. and Marshall-Gradisnik, S.M. (2011a) MicroRNAs Analysis in Cytotoxic Lymphocytes of Chronic Fatigue Syndrome/Myalgic Encephalomyelitis Patients. BMC Immunology.

Brenu, E.W., Staines, D.R., Baskurt, O.K., Ashton, K.J., Ramos, S.B., Christy, R.M. and Marshall-Gradisnik, S.M. (2010) Immune and hemorheological changes in chronic fatigue syndrome. Journal of translational medicine 8,1 .

Brenu, E.W., van Driel, M.L., Staines, D.R., Ashton, K.J., Ramos, S.B., Keane, J., Klimas, N.G. and Marshall-Gradisnik, S.M. (2011b) Immunological abnormalities as potential biomarkers in Chronic Fatigue Syndrome/Myalgic Encephalomyelitis. Journal of translational medicine 9,81 .

Bright, J.J., Kerr, L.D. and Sriram, S. (1997) TGF-beta inhibits IL-2-induced tyrosine phosphorylation and activation of Jak- 1 and Stat 5 in T lymphocytes. J Immunol 159, 175-83.

Brkic, S., Tomic, S., Ruzic, M. and Maric, D. (2011) Chronic fatigue syndrome. Srpski arhiv za celokupno lekarstvo 139, 256-61.

Broderick, G., Fuite, J., Kreitz, A., Vernon, S.D., Klimas, N. and Fletcher, M.A. (2010) A formal analysis of cytokine networks in chronic fatigue syndrome. Brain, behavior, and immunity 24, 1209-17.

Brown, E., Hooper, L., Ho, T. and Gresham, H. (1990) Integrin-associated protein: a 50-kD plasma membrane antigen physically and functionally associated with integrins. J Cell Biol 111, 2785-94.

Buchwald, D., Herrell, R., Ashton, S., Belcourt, M., Schmaling, K., Sullivan, P., Neale, M. and Goldberg, J. (2001) A twin study of chronic fatigue. Psychosom Med 63, 936-43.

Bushell, M., Wood, W., Clemens, M.J. and Morley, S.J. (2000) Changes in integrity and association of eukaryotic protein synthesis initiation factors during apoptosis. Eur J Biochem 267, 1083-91.

Cameron, B., Galbraith, S., Zhang, Y., Davenport, T., Vollmer-Conna, U., Wakefield, D., Hickie, I., Dunsmuir, W., Whistler, T., Vernon, S., Reeves, W.C. and Lloyd, A.R. (2007) Gene expression correlates of postinfective fatigue syndrome after infectious mononucleosis. J Infect Dis 196, 56-66. 
Campbell, I.K., Gerondakis, S., O'Donnell, K. and Wicks, I.P. (2000) Distinct roles for the NFkappaB1 (p50) and c-Rel transcription factors in inflammatory arthritis. J Clin Invest 105, 1799-806.

Carlo-Stella, N., Bozzini, S., De Silvestri, A., Sbarsi, I., Pizzochero, C., Lorusso, L., Martinetti, M. and Cuccia, M. (2009) Molecular study of receptor for advanced glycation endproduct gene promoter and identification of specific HLA haplotypes possibly involved in chronic fatigue syndrome. Int J Immunopathol Pharmacol 22, 745-54.

Carlson, M.E., Hsu, M. and Conboy, I.M. (2008) Imbalance between pSmad3 and Notch induce CDK inhibitors in old muscle stem cells. Nature 454, 528-32.

Carmel, L., Efroni, S., White, P.D., Aslakson, E., Vollmer-Conna, U. and Rajeevan, M.S. (2006) Gene expression profile of empirically delineated classes of unexplained chronic fatigue. Pharmacogenomics 7, 375-86.

Carmeliet, P. and Tessier-Lavigne, M. (2005) Common mechanisms of nerve and blood vessel wiring. Nature 436, 193-200.

Carruthers, B.M., van de Sande, M.I., De Meirleir, K.L., Klimas, N.G., Broderick, G., Mitchell, T., Staines, D., Powles, A.P., Speight, N., Vallings, R., Bateman, L., BaumgartenAustrheim, B., Bell, D.S., Carlo-Stella, N., Chia, J., Darragh, A., Jo, D., Lewis, D., Light, A.R., Marshall-Gradisbik, S., Mena, I., Mikovits, J.A., Miwa, K., Murovska, M., Pall, M.L. and Stevens, S. (2011) Myalgic Encephalomyelitis: International Consensus Criteria. Journal of internal medicine.

Carruthers, B.M., Jain, A.K., de Meirleir, K.L., Peterson, D.L., Klimas, N.G., Lerner, M., Bested, A.C., Flor-Henry, P., Joshi, P., Powles, A.C.P., Sherkey, J.A. \& van de Sande, M.I. (2003) Myalgic Encephalomyelitis/Chronic Fatigue Syndrome:Clinical Working Case Definition, Diagnostic and Treatment Protocols. Journal of Chronic Fatigue, 11, 7-154.

Chen, J.F., Mandel, E.M., Thomson, J.M., Wu, Q., Callis, T.E., Hammond, S.M., Conlon, F.L. and Wang, D.Z. (2006) The role of microRNA-1 and microRNA-133 in skeletal muscle proliferation and differentiation. Nature genetics 38, 228-33.

Cheung, V.G. and Spielman, R.S. (2009) Genetics of human gene expression: mapping DNA variants that influence gene expression. Nat Rev Genet 10, 595-604.

Choy, L., Skillington, J. and Derynck, R. (2000) Roles of autocrine TGF-beta receptor and Smad signaling in adipocyte differentiation. J Cell Biol 149, 667-82.

Claypoole, K.H., Noonan, C., Mahurin, R.K., Goldberg, J., Erickson, T. and Buchwald, D. (2007) A twin study of cognitive function in chronic fatigue syndrome: the effects of sudden illness onset. Neuropsychology 21, 507-13.

Cobb, B.S., Hertweck, A., Smith, J., O'Connor, E., Graf, D., Cook, T., Smale, S.T., Sakaguchi, S., Livesey, F.J., Fisher, A.G. and Merkenschlager, M. (2006) A role for Dicer in immune regulation. J Exp Med 203, 2519-27.

Coffer, P.J. and Burgering, B.M. (2004) Forkhead-box transcription factors and their role in the immune system. Nat Rev Immunol 4, 889-99.

Cogliati, T., Good, D.J., Haigney, M., Delgado-Romero, P., Eckhaus, M.A., Koch, W.J. and Kirsch, I.R. (2002) Predisposition to arrhythmia and autonomic dysfunction in Nhlh1-deficient mice. Mol Cell Biol 22, 4977-83.

Crabtree, G.R. and Clipstone, N.A. (1994) Signal transmission between the plasma membrane and nucleus of T lymphocytes. Annu Rev Biochem 63, 1045-83. 
Crawley, E. and Smith, G.D. (2207) Is Chronic Fatigue Syndrome (CFS/ME) heritable in children, and if so, why does it matter? Arch Dis Child 92, 1058-1061.

Croker, B.A., Krebs, D.L., Zhang, J.G., Wormald, S., Willson, T.A., Stanley, E.G., Robb, L., Greenhalgh, C.J., Forster, I., Clausen, B.E., Nicola, N.A., Metcalf, D., Hilton, D.J., Roberts, A.W. and Alexander, W.S. (2003) SOCS3 negatively regulates IL-6 signaling in vivo. Nat Immunol 4, 540-5.

Darash-Yahana, M., Pikarsky, E., Abramovitch, R., Zeira, E., Pal, B., Karplus, R., Beider, K., Avniel, S., Kasem, S., Galun, E. and Peled, A. (2004) Role of high expression levels of CXCR4 in tumor growth, vascularization, and metastasis. FASEB J 18, 1240-2.

David, M. (2002) Signal transduction by type I interferons. Biotechniques Suppl, 58-65.

de Lange, F.P., Kalkman, J.S., Bleijenberg, G., Hagoort, P., van der Meer, J.W. and Toni, I. $(2005)$ Gray matter volume reduction in the chronic fatigue syndrome. Neuroimage 26, 777-81.

de Ruijter, A.J., van Gennip, A.H., Caron, H.N., Kemp, S. and van Kuilenburg, A.B. (2003) Histone deacetylases (HDACs): characterization of the classical HDAC family. Biochem J 370, 737-49.

De Smaele, E., Fragomeli, C., Ferretti, E., Pelloni, M., Po, A., Canettieri, G., Coni, S., Di Marcotullio, L., Greco, A., Moretti, M., Di Rocco, C., Pazzaglia, S., Maroder, M., Screpanti, I., Giannini, G. and Gulino, A. (2008) An integrated approach identifies Nhlh1 and Insm1 as Sonic Hedgehog-regulated genes in developing cerebellum and medulloblastoma. Neoplasia 10, 89-98.

Delvig, A.A., Lee, J.J., Chrzanowska-Lightowlers, Z.M. and Robinson, J.H. (2002) TGF-beta1 and IFN-gamma cross-regulate antigen presentation to CD4 $\mathrm{T}$ cells by macrophages. J Leukoc Biol 72, 163-6.

Demitrack, M.A. (1997) Neuroendocrine correlates of chronic fatigue syndrome: a brief review. J Psychiatr Res 31, 69-82.

Derynck, R. and Zhang, Y.E. (2003) Smad-dependent and Smad-independent pathways in TGF-beta family signalling. Nature $425,577-84$.

Dittmer, J. (2003) The biology of the Ets1 proto-oncogene. Mol Cancer 2, 29.

Domingo-Gil, E., Gonzalez, J.M. and Esteban, M. (2010) Identification of cellular genes induced in human cells after activation of the OAS/RNaseL pathway by vaccinia virus recombinants expressing these antiviral enzymes. J Interferon Cytokine Res 30, 171-88.

Dommisch, H., Acil, Y., Dunsche, A., Winter, J. and Jepsen, S. (2005) Differential gene expression of human beta-defensins (hBD-1, -2, -3) in inflammatory gingival diseases. Oral Microbiol Immunol 20, 186-90.

Ejima, K., Nanri, H., Araki, M., Koji, T., Shibata, E., Kashimura, M. and Ikeda, M. (2000) Expression of mitochondrial thioredoxin-dependent antioxidant protein, SP-22, in normal human and inflammatory mouse placentae. Placenta 21, 847-52.

Evengard, B., Jacks, A., Pedersen, N.L. and Sullivan, P.F. (2005) The epidemiology of chronic fatigue in the Swedish Twin Registry. Psychol Med 35, 1317-26.

Fang, H., Xie, Q., Boneva, R., Fostel, J., Perkins, R. and Tong, W. (2006) Gene expression profile exploration of a large dataset on chronic fatigue syndrome. Pharmacogenomics 7, 429-40.

Farnham, P.J. (2009) Insights from genomic profiling of transcription factors. Nat Rev Genet $10,605-16$. 
Fathallah-Shaykh, H.M. (2005) Microarrays: applications and pitfalls. Archives of neurology 62, 1669-72.

Feng, S., Deng, L., Chen, W., Shao, J., Xu, G. and Li, Y.P. (2009) Atp6v1c1 is an essential component of the osteoclast proton pump and in F-actin ring formation in osteoclasts. Biochem J 417, 195-203.

Fletcher, M.A., Zeng, X.R., Barnes, Z., Levis, S. and Klimas, N.G. (2009) Plasma cytokines in women with chronic fatigue syndrome. Journal of translational medicine 7, 96.

Flex, E., Petrangeli, V., Stella, L., Chiaretti, S., Hornakova, T., Knoops, L., Ariola, C., Fodale, V., Clappier, E., Paoloni, F., Martinelli, S., Fragale, A., Sanchez, M., Tavolaro, S., Messina, M., Cazzaniga, G., Camera, A., Pizzolo, G., Tornesello, A., Vignetti, M., Battistini, A., Cave, H., Gelb, B.D., Renauld, J.C., Biondi, A., Constantinescu, S.N., Foa, R. and Tartaglia, M. (2008) Somatically acquired JAK1 mutations in adult acute lymphoblastic leukemia. J Exp Med 205, 751-8.

Foster, N., Lea, S.R., Preshaw, P.M. and Taylor, J.J. (2007) Pivotal advance: vasoactive intestinal peptide inhibits up-regulation of human monocyte TLR2 and TLR4 by LPS and differentiation of monocytes to macrophages. J Leukoc Biol 81, 893-903.

Fukuda, K., Straus, S.E., Hickie, I., Sharpe, M.C., Dobbins, J.G. and Komaroff, A. (1994) The chronic fatigue syndrome: a comprehensive approach to its definition and study. International Chronic Fatigue Syndrome Study Group. Ann Intern Med, 121, 953-9.

Gao, A.G., Lindberg, F.P., Finn, M.B., Blystone, S.D., Brown, E.J. and Frazier, W.A. (1996) Integrin-associated protein is a receptor for the C-terminal domain of thrombospondin. J Biol Chem 271, 21-4.

Gegonne, A., Bosselut, R., Bailly, R.A. and Ghysdael, J. (1993) Synergistic activation of the HTLV1 LTR Ets-responsive region by transcription factors Ets1 and Sp1. EMBO J 12, 1169-78.

Gerondakis, S. and Siebenlist, U. (2010) Roles of the NF-kappaB pathway in lymphocyte development and function. Cold Springs Harb Perspect Biol 2, a000182.

Giese, K., Kingsley, C., Kirshner, J.R. and Grosschedl, R. (1995) Assembly and function of a TCR alpha enhancer complex is dependent on LEF-1-induced DNA bending and multiple protein-protein interactions. Genes Dev 9, 995-1008.

Goldfeld, A.E., Strominger, J.L. and Doyle, C. (1991) Human tumor necrosis factor alpha gene regulation in phorbol ester stimulated T and B cell lines. J Exp Med 174, 73-81.

Gotoh, Y., Oishi, K., Shibata, H., Yamagiwa, A., Isagawa, T., Nishimura, T., Goyama, E., Takahashi, M., Mukai, H. and Ono, Y. (2004) Protein kinase PKN1 associates with TRAF2 and is involved in TRAF2-NF-kappaB signaling pathway. Biochem Biophys Res Commun 314, 688-94.

Gow, J.W., Hagan, S., Herzyk, P., Cannon, C., Behan, P.O. and Chaudhuri, A. (2009) A gene signature for post-infectious chronic fatigue syndrome. BMC medical genomics 2, 38.

Gros, M.J., Naquet, P. and Guinamard, R.R. (2008) Cell intrinsic TGF-beta 1 regulation of B cells. J Immunol 180, 8153-8.

Groussin, L., Kirschner, L.S., Vincent-Dejean, C., Perlemoine, K., Jullian, E., Delemer, B., Zacharieva, S., Pignatelli, D., Carney, J.A., Luton, J.P., Bertagna, X., Stratakis, C.A. and Bertherat, J. (2002) Molecular analysis of the cyclic AMP-dependent protein kinase A (PKA) regulatory subunit 1A (PRKAR1A) gene in patients with Carney complex and primary pigmented nodular adrenocortical disease (PPNAD) reveals 
novel mutations and clues for pathophysiology: augmented PKA signaling is associated with adrenal tumorigenesis in PPNAD. Am J Hum Genet 71, 1433-42.

Gu, T.L., Goetz, T.L., Graves, B.J. and Speck, N.A. (2000) Auto-inhibition and partner proteins, core-binding factor beta (CBFbeta) and Ets-1, modulate DNA binding by CBFalpha2 (AML1). Mol Cell Biol 20, 91-103.

Guis, D., Funk M.C., Chuang, E.Y., Feng, S., Huettner, P.C., Nguyen, L., Bradbury, C.M., Mishra, M., Gao, S., Buttin, B.M., Cohn, D.E., Powell, M.A., Horowitz, N.S., Whitcomb, B.P., Rader, J.S. (2007) Profiling microdissected epithelium and stroma to model genomic signatures for cervical carcinogenesis accommodating for covariates. Cancer Res 67, 7113-7123.

Gumy, L.F., Yeo, G.S., Tung, Y.C., Zivraj, K.H., Willis, D., Coppola, G., Lam, B.Y., Twiss, J.L., Holt, C.E. and Fawcett, J.W. (2011) Transcriptome analysis of embryonic and adult sensory axons reveals changes in mRNA repertoire localization. RNA 17, 85-98.

Gupta, S., Aggarwal, S., See, D. and Starr, A. (1997) Cytokine production by adherent and non-adherent mononuclear cells in chronic fatigue syndrome. J Psychiatr Res 31, 149-56.

Guschin, D., Rogers, N., Briscoe, J., Witthuhn, B., Watling, D., Horn, F., Pellegrini, S., Yasukawa, K., Heinrich, P., Stark, G.R. and et al. (1995) A major role for the protein tyrosine kinase JAK1 in the JAK/STAT signal transduction pathway in response to interleukin-6. EMBO J 14, 1421-9.

Ha, T.Y. (2011) The Role of MicroRNAs in Regulatory T Cells and in the Immune Response. Immune Netw 11, 11-41.

Hakeda, Y. and Kumegawa, M. (1991) [Osteoclasts in bone metabolism]. Kaibogaku Zasshi 66, 215-25.

Hauer, J., Puschner, S., Ramakrishnan, P., Simon, U., Bongers, M., Federle, C. and Engelmann, H. (2005) TNF receptor (TNFR)-associated factor (TRAF) 3 serves as an inhibitor of TRAF2/5-mediated activation of the noncanonical NF-kappaB pathway by TRAF-binding TNFRs. Proc Natl Acad Sci U S A 102, 2874-9.

Hayes, C.L., Spink, D.C., Spink, B.C., Cao, J.Q., Walker, N.J. and Sutter, T.R. (1996) 17 betaestradiol hydroxylation catalyzed by human cytochrome P450 1B1. Proc Natl Acad Sci U S A 93, 9776-81.

He, J.Q., Saha, S.K., Kang, J.R., Zarnegar, B. and Cheng, G. (2007) Specificity of TRAF3 in its negative regulation of the noncanonical NF-kappa B pathway. J Biol Chem 282, 3688-94.

He, J.Q., Zarnegar, B., Oganesyan, G., Saha, S.K., Yamazaki, S., Doyle, S.E., Dempsey, P.W. and Cheng, G. (2006) Rescue of TRAF3-null mice by p100 NF-kappa B deficiency. J Exp Med 203, 2413-8.

Hebenstreit, D., Horejs-Hoeck, J. and Duschl, A. (2005) JAK/STAT-dependent gene regulation by cytokines. Drug News Perspect 18, 243-9.

Hoe, H.S. and Rebeck, G.W. (2008) Regulated proteolysis of APP and ApoE receptors. Mol Neurobiol 37, 64-72.

Hokama, Y., Empey-Campora, C., Hara, C., Higa, N., Siu, N., Lau, R., Kuribayashi, T. and Yabusaki, K. (2008) Acute phase phospholipids related to the cardiolipin of mitochondria in the sera of patients with chronic fatigue syndrome (CFS), chronic Ciguatera fish poisoning (CCFP), and other diseases attributed to chemicals, Gulf War, and marine toxins. J Clin Lab Anal 22, 99-105. 
Howlin, J., Rosenkvist, J. and Andersson, T. (2008) TNK2 preserves epidermal growth factor receptor expression on the cell surface and enhances migration and invasion of human breast cancer cells. Breast Cancer Res 10, R36.

Huang, S., Pettaway, C.A., Uehara, H., Bucana, C.D. and Fidler, I.J. (2001) Blockade of NFkappaB activity in human prostate cancer cells is associated with suppression of angiogenesis, invasion, and metastasis. Oncogene 20, 4188-97.

Huang, Z., Fasco, M.J., Figge, H.L., Keyomarsi, K. and Kaminsky, L.S. (1996) Expression of cytochromes P450 in human breast tissue and tumors. Drug Metab Dispos 24, 899905.

Huber, A.R., Kunkel, S.L., Todd, R.F., 3rd and Weiss, S.J. (1991) Regulation of transendothelial neutrophil migration by endogenous interleukin-8. Science 254, 99-102.

Huh, M.I., Chang, Y. and Jung, J.C. (2009) Temporal and spatial distribution of TGF-beta isoforms and signaling intermediates in corneal regenerative wound repair. Histol Histopathol 24, 1405-16.

Hutvagner, G. and Zamore, P.D. (2002) A microRNA in a multiple-turnover RNAi enzyme complex. Science 297, 2056-60.

Ihle, J.N. (2001) The Stat family in cytokine signaling. Curr Opin Cell Biol 13, 211-7.

Inoue, A., Omoto, Y., Yamaguchi, Y., Kiyama, R. and Hayashi, S.I. (2004) Transcription factor EGR3 is involved in the estrogen-signaling pathway in breast cancer cells. Journal of molecular endocrinology 32, 649-61.

Ito, K., Hanazawa, T., Tomita, K., Barnes, P.J. and Adcock, I.M. (2004) Oxidative stress reduces histone deacetylase 2 activity and enhances IL-8 gene expression: role of tyrosine nitration. Biochem Biophys Res Commun 315, 240-5.

Itoh, S. and ten Dijke, P. (2007) Negative regulation of TGF-beta receptor/Smad signal transduction. Curr Opin Cell Biol 19, 176-84.

Jaeschke, A., Rincon, M., Doran, B., Reilly, J., Neuberg, D., Greiner, D.L., Shultz, L.D., Rossini, A.A., Flavell, R.A. and Davis, R.J. (2005) Disruption of the Jnk2 (Mapk9) gene reduces destructive insulitis and diabetes in a mouse model of type I diabetes. Proc Natl Acad Sci U S A 102, 6931-5.

Janssen, E.M., Droin, N.M., Lemmens, E.E., Pinkoski, M.J., Bensinger, S.J., Ehst, B.D., Griffith, T.S., Green, D.R. and Schoenberger, S.P. (2005) CD4+ T-cell help controls $\mathrm{CD}^{+}$T-cell memory via TRAIL-mediated activation-induced cell death. Nature 434, 88-93.

Jazin, E.E., Soderstrom, S., Ebendal, T. and Larhammar, D. (1997) Embryonic expression of the mRNA for the rat homologue of the fusin/CXCR-4 HIV-1 co-receptor. J Neuroimmunol 79, 148-54.

Jia, D., Rahbar, R., Chan, R.W., Lee, S.M., Chan, M.C., Wang, B.X., Baker, D.P., Sun, B., Peiris, J.S., Nicholls, J.M., Fish, E.N. (2010) Influenza virus non-structrual protein 1 (NS1) disrupt interferon signaling. PLoS One 5, e13927.

Jiang, H. and Wang, Y.C. (1996) [Cyclin-dependent kinase inhibitors in mammal cells]. Sheng Li Ke Xue Jin Zhan 27, 107-12.

Jiang, Y.M., Yamamoto, M., Kobayashi, Y., Yoshihara, T., Liang, Y., Terao, S., Takeuchi, H., Ishigaki, S., Katsuno, M., Adachi, H., Niwa, J., Tanaka, F., Doyu, M., Yoshida, M., Hashizume, Y. and Sobue, G. (2005) Gene expression profile of spinal motor neurons in sporadic amyotrophic lateral sclerosis. Annals of neurology 57, 236-51. 
Jones, D.E., Hollingsworth, K.G., Taylor, R., Blamire, A.M. and Newton, J.L. (2009) Abnormalities in $\mathrm{pH}$ handling by peripheral muscle and potential regulation by the autonomic nervous system in chronic fatigue syndrome. J Intern Med 267, 394-401.

Ju, X., Zenke, M., Hart, D.N. and Clark, G.J. (2008) CD300a/c regulate type I interferon and TNF-alpha secretion by human plasmacytoid dendritic cells stimulated with TLR7 and TLR9 ligands. Blood 112, 1184-94.

Kagami, S., Nakajima, H., Suto, A., Hirose, K., Suzuki, K., Morita, S., Kato, I., Saito, Y., Kitamura, T. and Iwamoto, I. (2001) Stat5a regulates T helper cell differentiation by several distinct mechanisms. Blood 97, 2358-65.

Kajimoto, K., Shao, D., Takagi, H., Maceri, G., Zablocki, D., Mukai, H., Ono, Y. and Sadoshima, J. (2011) Hypotonic swelling-induced activation of PKN1 mediates cell survival in cardiac myocytes. American journal of physiology. Heart and circulatory physiology 300, H191-200.

Kamimura, D., Ishihara, K. and Hirano, T. (2003) IL-6 signal transduction and its physiological roles: the signal orchestration model. Rev Physiol Biochem Pharmacol 149, 1-38.

Karvonen, U., Janne, O.A. and Palvimo, J.J. (2006) Androgen receptor regulates nuclear trafficking and nuclear domain residency of corepressor HDAC7 in a liganddependent fashion. Exp Cell Res 312, 3165-83.

Kasler, H.G. and Verdin, E. (2007) Histone deacetylase 7 functions as a key regulator of genes involved in both positive and negative selection of thymocytes. Mol Cell Biol 27, 5184-200.

Kato, T., Jr., Gotoh, Y., Hoffmann, A. and Ono, Y. (2008) Negative regulation of constitutive NF-kappaB and JNK signaling by PKN1-mediated phosphorylation of TRAF1. Genes Cells 13, 509-20.

Kaushik, N., Fear, D., Richards, S.C., McDermott, C.R., Nuwaysir, E.F., Kellam, P., Harrison, T.J., Wilkinson, R.J., Tyrrell, D.A., Holgate, S.T. and Kerr, J.R. (2005) Gene expression in peripheral blood mononuclear cells from patients with chronic fatigue syndrome. J Clin Pathol 58, 826-32.

Kayagaki, N., Yamaguchi, N., Nakayama, M., Eto, H., Okumura, K. and Yagita, H. (1999) Type I interferons (IFNs) regulate tumor necrosis factor-related apoptosis-inducing ligand (TRAIL) expression on human T cells: A novel mechanism for the antitumor effects of type I IFNs. J Exp Med 189, 1451-60.

Kennedy, G., Spence, V., Underwood, C. and Belch, J.J. (2004) Increased neutrophil apoptosis in chronic fatigue syndrome. J Clin Pathol 57, 891-3.

Kerr, J.R. (2008) Gene profiling of patients with chronic fatigue syndrome/myalgic encephalomyelitis. Curr Rheumatol Rep 10, 482-91.

Kerr, J.R., Petty, R., Burke, B., Gough, J., Fear, D., Sinclair, L.I., Mattey, D.L., Richards, S.C., Montgomery, J., Baldwin, D.A., Kellam, P., Harrison, T.J., Griffin, G.E., Main, J., Enlander, D., Nutt, D.J. and Holgate, S.T. (2008) Gene expression subtypes in patients with chronic fatigue syndrome/myalgic encephalomyelitis. J Infect Dis 197, 1171-84.

Khvorova, A., Lescoute, A., Westhof, E. and Jayasena, S.D. (2003) Sequence elements outside the hammerhead ribozyme catalytic core enable intracellular activity. Nat Struct Biol 10, 708-12. 
Kim, S.H., Serezani, C.H., Okunishi, K., Zaslona, Z., Aronoff, D.M. and Peters-Golden, M. (2011) Distinct protein kinase A anchoring proteins direct prostaglandin E2 modulation of Toll-like receptor signaling in alveolar macrophages. J Biol Chem 286, 8875-83.

Kitamura, H., Kanehira, K., Okita, K., Morimatsu, M. and Saito, M. (2000) MAIL, a novel nuclear I kappa B protein that potentiates LPS-induced IL-6 production. FEBS Lett 485, 53-6.

Kohlhaas, S., Garden, O.A., Scudamore, C., Turner, M., Okkenhaug, K. and Vigorito, E. (2009) Cutting edge: the Foxp3 target miR-155 contributes to the development of regulatory T cells. J Immunol 182, 2578-82.

Kristiansen, O.P. and Mandrup-Poulsen, T. (2005) Interleukin-6 and diabetes: the good, the bad, or the indifferent? Diabetes 54 Suppl 2, S114-24.

Kuratsune, H., Kondo, K., Ikuta, K., Yamanishi, K., Watanabe, Y. and Kitani, T. (2001) [Chronic fatigue syndrome (CFS)]. Nihon Naika Gakkai Zasshi 90, 2431-7.

Lacy, P. (2006) Mechanisms of degranulation in neutrophils. Allergy Asthma Clin Immunol 2, 98-108.

Lahmers, K.K., Hedges, J.F., Jutila, M.A., Deng, M., Abrahamsen, M.S. and Brown, W.C. (2006) Comparative gene expression by $\mathrm{WC}^{+}$gammadelta and $\mathrm{CD} 4{ }^{+}$alphabeta $\mathrm{T}$ lymphocytes, which respond to Anaplasma marginale, demonstrates higher expression of chemokines and other myeloid cell-associated genes by $\mathrm{WC1}^{+}$ gammadelta T cells. Journal of leukocyte biology 80, 939-52.

Lange, G., DeLuca, J., Maldjian, J.A., Lee, H., Tiersky, L.A. and Natelson, B.H. (1999) Brain MRI abnormalities exist in a subset of patients with chronic fatigue syndrome. J Neurol Sci 171, 3-7.

Lee, K.M., Jeon, S.M. and Cho, H.J. (2009) Tumor necrosis factor receptor 1 induces interleukin-6 upregulation through NF-kappaB in a rat neuropathic pain model. Eur J Pain 13, 794-806.

Leong J.W. and Fehniger, T. (2010) Human NK SET to kill. Blood 24, 117-118.

R., Lee, Y., Ahn, C., Han, J., Choi, H., Kim, J., Yim, J., Lee, J., Provost, P., Radmark, O., Kim, S. and Kim, V.N. (2003) The nuclear RNase III Drosha initiates microRNA processing. Nature 425, 415-9.

Lee, Y., Jeon, K., Lee, J.T., Kim, S. and Kim, V.N. (2002) MicroRNA maturation: stepwise processing and subcellular localization. EMBO J 21, 4663-70.

Leung, L. and Cahill, C.M. (2010) TNF-alpha and neuropathic pain--a review. J Neuroinflammation 7, 27.

Li, Q.J., Chau, J., Ebert, P.J., Sylvester, G., Min, H., Liu, G., Braich, R., Manoharan, M., Soutschek, J., Skare, P., Klein, L.O., Davis, M.M. and Chen, C.Z. (2007) miR-181a is an intrinsic modulator of T cell sensitivity and selection. Cell 129, 147-61.

Li, W. and Ruan, K. (2009) MicroRNA detection by microarray. Analytical and bioanalytical chemistry 394, 1117-24.

Light, A.R., White, A.T., Hughen, R.W. and Light, K.C. (2009) Moderate Exercise Increases Expression for Sensory, Adrenergic, and Immune Genes in Chronic Fatigue Syndrome Patients But Not in Normal Subjects. J Pain.

Lim, L.P., Lau, N.C., Garrett-Engele, P., Grimson, A., Schelter, J.M., Castle, J., Bartel, D.P., Linsley, P.S. and Johnson, J.M. (2005) Microarray analysis shows that some microRNAs downregulate large numbers of target mRNAs. Nature 433, 769-73. 
Lin, J.X. and Leonard, W.J. (2000) The role of Stat5a and Stat5b in signaling by IL-2 family cytokines. Oncogene 19, 2566-76.

Lindberg, F.P., Gresham, H.D., Schwarz, E. and Brown, E.J. (1993) Molecular cloning of integrin-associated protein: an immunoglobulin family member with multiple membrane-spanning domains implicated in alpha $\mathrm{v}$ beta 3-dependent ligand binding. J Cell Biol 123, 485-96.

Lingel, A., Simon, B., Izaurralde, E. and Sattler, M. (2003) Structure and nucleic-acid binding of the Drosophila Argonaute 2 PAZ domain. Nature 426, 465-9.

Lloyd, A.R., Hickie, I., Boughton, C.R., Spencer, O. and Wakefield, D. (1990) Prevalence of chronic fatigue syndrome in an Australian population. Med J Australia 153, 522528 .

Lu, J., Getz, G., Miska, E.A., Alvarez-Saavedra, E., Lamb, J., Peck, D., Sweet-Cordero, A., Ebert, B.L., Mak, R.H., Ferrando, A.A., Downing, J.R., Jacks, T., Horvitz, H.R. and Golub, T.R. (2005) MicroRNA expression profiles classify human cancers. Nature 435, 834-8.

Lu, L.F., Thai, T.H., Calado, D.P., Chaudhry, A., Kubo, M., Tanaka, K., Loeb, G.B., Lee, H., Yoshimura, A., Rajewsky, K. and Rudensky, A.Y. (2009) Foxp3-dependent microRNA155 confers competitive fitness to regulatory T cells by targeting SOCS1 protein. Immunity 30, 80-91.

Lu, Y.C., Yeh, W.C. and Ohashi, P.S. (2008) LPS/TLR4 signal transduction pathway. Cytokine 42, 145-51.

Madueno, J.A., Munoz, E., Blazquez, V., Gonzalez, R., Aparicio, P. and Pena, J. (1993) The CD26 antigen is coupled to protein tyrosine phosphorylation and implicated in CD16-mediated lysis in natural killer cells. Scandinavian journal of immunology 37, 425-9.

Maher, K.J., Klimas, N.G. and Fletcher, M.A. (2005) Chronic fatigue syndrome is associated with diminished intracellular perforin. Clinical and experimental immunology 142, 505-11.

Marie, J.C., Letterio, J.J., Gavin, M. and Rudensky, A.Y. (2005) TGF-beta1 maintains suppressor function and Foxp3 expression in $\mathrm{CD} 4{ }^{+} \mathrm{CD} 25^{+}$regulatory T cells. J Exp Med 201, 1061-7.

Marson, A., Kretschmer, K., Frampton, G.M., Jacobsen, E.S., Polansky, J.K., MacIsaac, K.D., Levine, S.S., Fraenkel, E., von Boehmer, H. and Young, R.A. (2007) Foxp3 occupancy and regulation of key target genes during T-cell stimulation. Nature 445, 931-5.

Matsuoka, M. and Jeang, K.T. (2005) Human T-cell leukemia virus type I at age 25: a progress report. Cancer Res 65, 4467-70.

McGeachy, M.J. and Cua, D.J. (2007) T cells doing it for themselves: TGF-beta regulation of Th1 and Th17 cells. Immunity 26, 547-9.

McGuire, M.J., Lipsky, P.E. and Thiele, D.L. (1997) Cloning and characterization of the cDNA encoding mouse dipeptidyl peptidase I (cathepsin C). Biochim Biophys Acta 1351, 267-73.

Meyer-Lindenberg, A., Kohn, P.D., Kolachana, B., Kippenhan, S., McInerney-Leo, A., Nussbaum, R., Weinberger, D.R. and Berman, K.F. (2005) Midbrain dopamine and prefrontal function in humans: interaction and modulation by COMT genotype. Nat Neurosci 8, 594-6. 
Miller, C., Wang, L., Ostergaard, E., Dan, P. and Saada, A. (2011) The interplay between SUCLA2, SUCLG2, and mitochondrial DNA depletion. Biochim Biophys Acta 1812, 625-9.

Mishima, Y., Giraldez, A.J., Takeda, Y., Fujiwara, T., Sakamoto, H., Schier, A.F. and Inoue, K. (2006) Differential regulation of germline mRNAs in soma and germ cells by zebrafish miR-430. Curr Biol 16, 2135-42.

Moepps, B., Frodl, R., Rodewald, H.R., Baggiolini, M. and Gierschik, P. (1997) Two murine homologues of the human chemokine receptor CXCR4 mediating stromal cellderived factor 1alpha activation of Gi2 are differentially expressed in vivo. Eur J Immunol 27, 2102-12.

Moore, K.W., de Waal Malefyt, R., Coffman, R.L. and O'Garra, A. (2001) Interleukin-10 and the interleukin-10 receptor. Annu Rev Immunol 19, 683-765.

Morin, R.D., O'Connor, M.D., Griffith, M., Kuchenbauer, F., Delaney, A., Prabhu, A.L., Zhao, Y., McDonald, H., Zeng, T., Hirst, M., Eaves, C.J. and Marra, M.A. (2008) Application of massively parallel sequencing to microRNA profiling and discovery in human embryonic stem cells. Genome research 18, 610-21.

Moriuchi, M., Moriuchi, H., Turner, W. and Fauci, A.S. (1998) Exposure to bacterial products renders macrophages highly susceptible to T-tropic HIV-1. J Clin Invest 102, 154050.

Morrison, G., Kilanowski, F., Davidson, D. and Dorin, J. (2002) Characterization of the mouse beta defensin 1, Defb1, mutant mouse model. Infect Immun 70, 3053-60.

Moser, C., Weiner, D.J., Lysenko, E., Bals, R., Weiser, J.N. and Wilson, J.M. (2002) betaDefensin 1 contributes to pulmonary innate immunity in mice. Infect Immun 70, 3068-72.

Mourelatos, Z., Dostie, J., Paushkin, S., Sharma, A., Charroux, B., Abel, L., Rappsilber, J., Mann, M. and Dreyfuss, G. (2002) miRNPs: a novel class of ribonucleoproteins containing numerous microRNAs. Genes Dev 16, 720-8.

Mukaida, N. (2003) Pathophysiological roles of interleukin-8/CXCL8 in pulmonary diseases. Am J Physiol Lung Cell Mol Physiol 284, L566-77.

Myhill, S., Booth, N.E. and McLaren-Howard, J. (2009) Chronic fatigue syndrome and mitochondrial dysfunction. Int J Clin Exp Med 2, 1-16.

Newton, J.L., Okonkwo, O., Sutcliffe, K., Seth, A., Shin, J. and Jones, D.E. (2007) Symptoms of autonomic dysfunction in chronic fatigue syndrome. QJM 100, 519-26.

Nizet, V. and Johnson, R.S. (2009) Interdependence of hypoxic and innate immune responses. Nat Rev Immunol 9, 609-17.

Nowlan, M.L., Drewe, E., Bulsara, H., Esposito, N., Robins, R.A., Tighe, P.J., Powell, R.J. and Todd, I. (2006) Systemic cytokine levels and the effects of etanercept in TNF receptor-associated periodic syndrome (TRAPS) involving a C33Y mutation in TNFRSF1A. Rheumatology (Oxford) 45, 31-7.

Nozell, S., Laver, T., Patel, K. and Benveniste, E.N. (2006) Mechanism of IFN-beta-mediated inhibition of IL-8 gene expression in astroglioma cells. J Immunol 177, 822-30.

O'Connell, R.M., Taganov, K.D., Boldin, M.P., Cheng, G. and Baltimore, D. (2007) MicroRNA-155 is induced during the macrophage inflammatory response. Proc Natl Acad Sci U S A 104, 1604-9.

O'Shea, J.J., Gadina, M. and Schreiber, R.D. (2002) Cytokine signaling in 2002: new surprises in the Jak/Stat pathway. Cell 109 Suppl, S121-31. 
Oberle, N., Eberhardt, N., Falk, C.S., Krammer, P.H. and Suri-Payer, E. (2007) Rapid suppression of cytokine transcription in human $\mathrm{CD} 4{ }^{+} \mathrm{CD} 25 \mathrm{~T}$ cells by $\mathrm{CD} 4{ }^{+} \mathrm{Foxp} 3^{+}$ regulatory T cells: independence of IL-2 consumption, TGF-beta, and various inhibitors of TCR signaling. J Immunol 179, 3578-87.

Orlinick, J.R. and Chao, M.V. (1998) TNF-related ligands and their receptors. Cell Signal 10, 543-51.

Panousis, C.G., Evans, G. and Zuckerman, S.H. (2001) TGF-beta increases cholesterol efflux and $\mathrm{ABC}-1$ expression in macrophage-derived foam cells: opposing the effects of IFN-gamma. J Lipid Res 42, 856-63.

Park, J.H. and Levitt, L. (1993) Overexpression of mitogen-activated protein kinase (ERK1) enhances T-cell cytokine gene expression: role of AP1, NF-AT, and NF-KB. Blood $82,2470-7$.

Parkos, C.A., Colgan, S.P., Liang, T.W., Nusrat, A., Bacarra, A.E., Carnes, D.K. and Madara, J.L. (1996) CD47 mediates post-adhesive events required for neutrophil migration across polarized intestinal epithelia. J Cell Biol 132, 437-50.

Pasi, A., Bozzini, S., Carlo-Stella, N., Martinetti, M., Bombardieri, S., De Silvestri, A., Salvaneschi, L. and Cuccia, M. (2011) Excess of activating killer cell immunoglobulinlike receptors and lack of HLA-Bw4 ligands: a twoedged weapon in chronic fatigue syndrome. Molecular medicine reports 4, 535-40.

Pham, C.T. and Ley, T.J. (1999) Dipeptidyl peptidase I is required for the processing and activation of granzymes A and B in vivo. Proc Natl Acad Sci U S A 96, 8627-32.

Pickering, M., Cumiskey, D. and O'Connor, J.J. (2005) Actions of TNF-alpha on glutamatergic synaptic transmission in the central nervous system. Exp Physiol 90, 663-70.

Pierce, K.L., Premont, R.T. and Lefkowitz, R.J. (2002) Seven-transmembrane receptors. Nat Rev Mol Cell Biol 3, 639-50.

Plioplys, A.V. and Plioplys, S. (1995) Electron-microscopic investigation of muscle mitochondria in chronic fatigue syndrome. Neuropsychobiology 32, 175-81.

Pollard, T.D. (2007) Regulation of actin filament assembly by Arp2/3 complex and formins. Annu Rev Biophys Biomol Struct 36, 451-77.

Pradelli, L.A., Beneatea, M., Ricci, J.E. (2010) Mitchondrialcontrol of caspases-dependent and -independent cell death.Cell Mol Life Sci 67, 15898

Presson, A.P., Sobel, E.M., Papp, J.C., Suarez, C.J., Whistler, T., Rajeevan, M.S., Vernon, S.D. and Horvath, S. (2008) Integrated weighted gene co-expression network analysis with an application to chronic fatigue syndrome. BMC Syst Biol 2, 95.

Rajeevan, M.S., Smith, A.K., Dimulescu, I., Unger, E.R., Vernon, S.D., Heim, C. and Reeves, W.C. (2007) Glucocorticoid receptor polymorphisms and haplotypes associated with chronic fatigue syndrome. Genes Brain Behav 6, 167-76.

Rameil, P., Lecine, P., Ghysdael, J., Gouilleux, F., Kahn-Perles, B. and Imbert, J. (2000) IL-2 and long-term $\mathrm{T}$ cell activation induce physical and functional interaction between STAT5 and ETS transcription factors in human T cells. Oncogene 19, 2086-97.

Rao, A., Luo, C. and Hogan, P.G. (1997a) Transcription factors of the NFAT family: regulation and function. Annu Rev Immunol 15, 707-47.

Rao, N.V., Rao, G.V. and Hoidal, J.R. (1997b) Human dipeptidyl-peptidase I. Gene characterization, localization, and expression. J Biol Chem 272, 10260-5. 
Reynolds, C.A., Hong, M.G., Eriksson, U.K., Blennow, K., Johansson, B., Malmberg, B., Berg, S., Gatz, M., Pedersen, N.L., Bennet, A.M. and Prince, J.A. (2010) Sequence variation in SORL1 and dementia risk in Swedes. Neurogenetics 11, 139-42.

Reynolds, G.P., Templeman, L.A. and Godlewska, B.R. (2006) Pharmacogenetics of schizophrenia. Expert opinion on pharmacotherapy 7, 1429-40.

Rodriguez, A., Vigorito, E., Clare, S., Warren, M.V., Couttet, P., Soond, D.R., van Dongen, S., Grocock, R.J., Das, P.P., Miska, E.A., Vetrie, D., Okkenhaug, K., Enright, A.J., Dougan, G., Turner, M. and Bradley, A. (2007) Requirement of bic/microRNA-155 for normal immune function. Science 316, 608-11.

Rorbach, J., Richter, R., Wessels, H.J., Wydro, M., Pekalski, M., Farhoud, M., Kuhl, I., Gaisne, M., Bonnefoy, N., Smeitink, J.A., Lightowlers, R.N. and Chrzanowska-Lightowlers, Z.M. (2008) The human mitochondrial ribosome recycling factor is essential for cell viability. Nucleic Acids Res 36, 5787-99.

Russell, L. and Garrett-Sinha, L.A. (2010) Transcription factor Ets-1 in cytokine and chemokine gene regulation. Cytokine 51, 217-26.

Safford, M., Collins, S., Lutz, M.A., Allen, A., Huang, C.T., Kowalski, J., Blackford, A., Horton, M.R., Drake, C., Schwartz, R.H. and Powell, J.D. (2005) Egr-2 and Egr-3 are negative regulators of $\mathrm{T}$ cell activation. Nat Immunol 6, 472-80.

Saiki, T., Kawai, T., Morita, K., Ohta, M., Saito, T., Rokutan, K. and Ban, N. (2008) Identification of marker genes for differential diagnosis of chronic fatigue syndrome. Mol Med 14, 599-607.

Salaun, B., Yamamoto, T., Badran, B., Tsunetsugu-Yokota, Y., Roux, A., Baitsch, L., Rouas, R., Fayyad-Kazan, H., Baumgaertner, P., Devevre, E., Ramesh, A., Braun, M., Speiser, D., Autran, B., Martiat, P., Appay, V. and Romero, P. (2011) Differentiation associated regulation of microRNA expression in vivo in human $\mathrm{CD}^{+} \mathrm{T}$ cell subsets. Journal of translational medicine 9,44 .

Sanchez-Capelo, A. (2005) Dual role for TGF-beta1 in apoptosis. Cytokine Growth Factor Rev 16, 15-34.

Schaefer, U., Voloshanenko, O., Willen, D. and Walczak, H. (2007) TRAIL: a multifunctional cytokine. Front Biosci 12, 3813-24.

Schindler, C. (1999) Cytokines and JAK-STAT signaling. Exp Cell Res 253, 7-14.

Schindler, C., Levy, D.E. and Decker, T. (2007) JAK-STAT signaling: from interferons to cytokines. J Biol Chem 282, 20059-63.

Schutzer, S.E., Angel, T.E., Liu, T., Schepmoes, A.A., Clauss, T.R., Adkins, J.N., Camp, D.G., Holland, B.K., Bergquist, J., Coyle, P.K., Smith, R.D., Fallon, B.A. and Natelson, B.H. (2011a) Distinct cerebrospinal fluid proteomes differentiate post-treatment lyme disease from chronic fatigue syndrome. PLoS One 6, e17287.

Schutzer, S.E., Rounds, M.A., Natelson, B.H., Ecker, D.J. and Eshoo, M.W. (2011b) Analysis of cerebrospinal fluid from chronic fatigue syndrome patients for multiple human ubiquitous viruses and xenotropic murine leukemia-related virus. Ann Neurol 69, 735-8.

Schwartz, R.B., Garada, B.M., Komaroff, A.L., Tice, H.M., Gleit, M., Jolesz, F.A. and Holman, B.L. (1994) Detection of intracranial abnormalities in patients with chronic fatigue syndrome: comparison of MR imaging and SPECT. AJR Am J Roentgenol 162, 93541.

Scott, J.D. (1991) Cyclic nucleotide-dependent protein kinases. Pharmacol Ther 50, 123-45. 
See, D.M., Cimoch, P., Chou, S., Chang, J. and Tilles, J. (1998) The in vitro immunomodulatory effects of glyconutrients on peripheral blood mononuclear cells of patients with chronic fatigue syndrome. Integr Physiol Behav Sci 33, 280-7.

Sen, G.C. (2001) Viruses and interferons. Annu Rev Microbiol 55, 255-81.

Sha, W.C., Liou, H.C., Tuomanen, E.I. and Baltimore, D. (1995) Targeted disruption of the p50 subunit of NF-kappa B leads to multifocal defects in immune responses. Cell 80, 321-30.

Sharpe, M.C., Archard, L.C., Bantanatvala, J.E., Borysiewicz, L.K., Clare, A.W., David, A., Edwards, R.H., Hawton, K.E., Lambert, H.P., Lane, R.J. \& et al. (1991) A report-chronic fatigue syndrome: guidelines for research. J R Soc Med, 84, 118-21.

Shen, Y.L., Jiang, Y.G., Greenlee, A.R., Zhou, L.L. and Liu, L.H. (2009) MicroRNA expression profiles and miR-10a target in anti-benzo[a] pyrene-7, 8-diol-9, 10-epoxidetransformed human 16HBE cells. Biomed Environ Sci 22, 14-21.

Shevach, E.M. (2010) TGF-Beta to the rescue. Immunity 32, 585-7.

Shibata, N., Ohnuma, T., Baba, H., Higashi, S., Nishioka, K. and Arai, H. (2008) Genetic association between SORL1 polymorphisms and Alzheimer's disease in a Japanese population. Dement Geriatr Cogn Disord 26, 161-4.

Shimada, T., Hayes, C.L., Yamazaki, H., Amin, S., Hecht, S.S., Guengerich, F.P. and Sutter, T.R. (1996) Activation of chemically diverse procarcinogens by human cytochrome P-450 1B1. Cancer Res 56, 2979-84.

Skowera, A., Cleare, A., Blair, D., Bevis, L., Wessely, S.C. and Peakman, M. (2004) High levels of type 2 cytokine-producing cells in chronic fatigue syndrome. Clin Exp Immunol 135, 294-302.

Sparkman, L. and Boggaram, V. (2004) Nitric oxide increases IL-8 gene transcription and mRNA stability to enhance IL-8 gene expression in lung epithelial cells. Am J Physiol Lung Cell Mol Physiol 287, L764-73.

Strobl, H. and Knapp, W. (1999) TGF-beta1 regulation of dendritic cells. Microbes Infect 1, 1283-90.

Studer, M., Gavalas, A., Marshall, H., Ariza-McNaughton, L., Rijli, F.M., Chambon, P. and Krumlauf, R. (1998) Genetic interactions between Hoxa1 and Hoxb1 reveal new roles in regulation of early hindbrain patterning. Development 125, 1025-36.

Su, D.M., Navarre, S., Oh, W.J., Condie, B.G. and Manley, N.R. (2003) A domain of Foxn1 required for crosstalk-dependent thymic epithelial cell differentiation. Nat Immunol 4, 1128-35.

Sun, L., Finnegan, C.M., Kish-Catalone, T., Blumenthal, R., Garzino-Demo, P., La Terra Maggiore, G.M., Berrone, S., Kleinman, C., Wu, Z., Abdelwahab, S., Lu, W. and Garzino-Demo, A. (2005) Human beta-defensins suppress human immunodeficiency virus infection: potential role in mucosal protection. J Virol 79, 14318-29.

Sun, W., Julie Li, Y.S., Huang, H.D., Shyy, J.Y. and Chien, S. (2010) microRNA: a master regulator of cellular processes for bioengineering systems. Annual review of biomedical engineering 12, 1-27.

Taganov, K.D., Boldin, M.P., Chang, K.J. and Baltimore, D. (2006) NF-kappaB-dependent induction of microRNA miR-146, an inhibitor targeted to signaling proteins of innate immune responses. Proc Natl Acad Sci U S A 103, 12481-6. 
Tasken, K., Skalhegg, B.S., Tasken, K.A., Solberg, R., Knutsen, H.K., Levy, F.O., Sandberg, M., Orstavik, S., Larsen, T., Johansen, A.K., Vang, T., Schrader, H.P., Reinton, N.T., Torgersen, K.M., Hansson, V. and Jahnsen, T. (1997) Structure, function, and regulation of human cAMP-dependent protein kinases. Adv Second Messenger Phosphoprotein Res 31, 191-204.

Thai, T.H., Calado, D.P., Casola, S., Ansel, K.M., Xiao, C., Xue, Y., Murphy, A., Frendewey, D., Valenzuela, D., Kutok, J.L., Schmidt-Supprian, M., Rajewsky, N., Yancopoulos, G., Rao, A. and Rajewsky, K. (2007) Regulation of the germinal center response by microRNA-155. Science 316, 604-8.

Ter Wolbeek, M., van Doornen, L.J.P., Kavelaars, A. And Heijnen, C.J. (2008) Predictors of persistent and new-onset of fatigue in adolescent girls. Pediatrics 121, e449.

Thomas, R.S., Tymms, M.J., McKinlay, L.H., Shannon, M.F., Seth, A. and Kola, I. (1997) ETS1, NFkappaB and AP1 synergistically transactivate the human GM-CSF promoter. Oncogene 14, 2845-55.

Ticchioni, M., Deckert, M., Mary, F., Bernard, G., Brown, E.J. and Bernard, A. (1997) Integrin-associated protein (CD47) is a comitogenic molecule on CD3-activated human T cells. J Immunol 158, 677-84.

Tili, E., Michaille, J.J., Cimino, A., Costinean, S., Dumitru, C.D., Adair, B., Fabbri, M., Alder, H., Liu, C.G., Calin, G.A. and Croce, C.M. (2007) Modulation of miR-155 and miR$125 \mathrm{~b}$ levels following lipopolysaccharide/TNF-alpha stimulation and their possible roles in regulating the response to endotoxin shock. J Immunol 179, 5082-9.

Turnbull, I.R. and Colonna, M. (2007) Activating and inhibitory functions of DAP12. Nat Rev Immunol 7, 155-61.

Ursini, F., Succurro, E., Grembiale, A., Gagliardi, D.A. and Arturi, F. (2010) [The HPA axis in the pathogenesis of chronic fatigue syndrome]. La Clinica terapeutica 161, 461-4.

Vernon, S.D., Unger, E.R., Dimulescu, I.M., Rajeevan, M. and Reeves, W.C. (2002) Utility of the blood for gene expression profiling and biomarker discovery in chronic fatigue syndrome. Disease markers 18, 193-9.

Vita, N., Lefort, S., Sozzani, P., Reeb, R., Richards, S., Borysiewicz, L.K., Ferrara, P. and Labeta, M.O. (1997) Detection and biochemical characteristics of the receptor for complexes of soluble CD14 and bacterial lipopolysaccharide. J Immunol 158, 345762.

Vojdani, A., Mordechai, E. and Brautbar, N. (1997) Abnormal apoptosis and cell cycle progression in humans exposed to methyl tertiary-butyl ether and benzene contaminating water. Hum Exp Toxicol 16, 485-94.

Waclavicek, M., Majdic, O., Stulnig, T., Berger, M., Baumruker, T., Knapp, W. and Pickl, W.F. (1997) T cell stimulation via CD47: agonistic and antagonistic effects of CD47 monoclonal antibody 1/1A4. J Immunol 159, 5345-54.

Wahl, S.M., Swisher, J., McCartney-Francis, N. and Chen, W. (2004) TGF-beta: the perpetrator of immune suppression by regulatory $\mathrm{T}$ cells and suicidal $\mathrm{T}$ cells. $\mathrm{J}$ Leukoc Biol 76, 15-24.

Wahl, S.M., Wen, J. and Moutsopoulos, N. (2006) TGF-beta: a mobile purveyor of immune privilege. Immunol Rev 213, 213-27.

Walsh, C.M., Zainal, N.Z., Middleton, S.J. and Paykel, E.S. (2001) A family history study of chronic fatigue syndrome. Psychiatric genetics 11, 123-8. 
Wang, M.J., Zhou, Z.G., Wang, L., Li, Y., Zhang, P., Zhang, Y., Cui, C.F. and Zhou, B. (2009a) [Genotyping of AKAP10 gene 2073A/G single nucleotide polymorphism by TaqMan probe real-time PCR]. Sichuan Da Xue Xue Bao Yi Xue Ban 40, 275-8.

Wang, M.J., Zhou, Z.G., Wang, L., Yu, Y.Y., Zhang, P., Zhang, Y., Cui, C.F., Yang, L., Li, Y., Zhou, B. and Sun, X.F. (2009b) The Ile646Val (2073A>G) polymorphism in the kinase-binding domain of A-kinase anchoring protein 10 and the risk of colorectal cancer. Oncology 76, 199-204.

Wang, S.E., Wu, F.Y., Shin, I., Qu, S. and Arteaga, C.L. (2005) Transforming growth factor (TGF-)-Smad target gene protein tyrosine phosphatase receptor type kappa is required for TGF- function. Mol Cell Biol 25, 4703-15.

Wang, X., Chen, Y., Ren, J. and Qu, X. (2011) Small interfering RNA for effective cancer therapies. Mini reviews in medicinal chemistry 11, 114-24.

Wang, D., John, S.A., Clements, J.L., Percy, D.H., Barton, K.P., Garrett-Sinha, L.A. (2005) Ets1 deficiency leads to altered B cell differentiation, hyperresponsiveness to TLR9 and autoimmune disease. Int Immunol 17, 1179-1191.

Washbourne, P., Thompson, P.M., Carta, M., Costa, E.T., Mathews, J.R., Lopez-Bendito, G., Molnar, Z., Becher, M.W., Valenzuela, C.F., Partridge, L.D. and Wilson, M.C. (2002) Genetic ablation of the t-SNARE SNAP-25 distinguishes mechanisms of neuroexocytosis. Nat Neurosci 5, 19-26.

Wasylyk, B., Hagman, J. and Gutierrez-Hartmann, A. (1998) Ets transcription factors: nuclear effectors of the Ras-MAP-kinase signaling pathway. Trends Biochem Sci 23, 213-6.

Wehkamp, J., Salzman, N.H., Porter, E., Nuding, S., Weichenthal, M., Petras, R.E., Shen, B., Schaeffeler, E., Schwab, M., Linzmeier, R., Feathers, R.W., Chu, H., Lima, H., Jr., Fellermann, K., Ganz, T., Stange, E.F. and Bevins, C.L. (2005) Reduced Paneth cell alpha-defensins in ileal Crohn's disease. Proc Natl Acad Sci U S A 102, 18129-34.

Whistler, T., Jones, J.F., Unger, E.R. and Vernon, S.D. (2005) Exercise responsive genes measured in peripheral blood of women with chronic fatigue syndrome and matched control subjects. BMC Physiol 5, 5 .

Whistler, T., Unger, E.R., Nisenbaum, R. and Vernon, S.D. (2003) Integration of gene expression, clinical, and epidemiologic data to characterize Chronic Fatigue Syndrome. J Transl Med 1, 10.

Wright, S.D., Ramos, R.A., Tobias, P.S., Ulevitch, R.J. and Mathison, J.C. (1990) CD14, a receptor for complexes of lipopolysaccharide (LPS) and LPS binding protein. Science 249, 1431-3.

Wu, H., Neilson, J.R., Kumar, P., Manocha, M., Shankar, P., Sharp, P.A. and Manjunath, N. (2007) miRNA Profiling of Nar"ve, Effector and Memory CD8 T Cells. PLoS One 2, e1020.

Wu, L., Fan, J. and Belasco, J.G. (2006) MicroRNAs direct rapid deadenylation of mRNA. Proc Natl Acad Sci U S A 103, 4034-9.

Wyrwicz, L.S., Gaj, P., Hoffmann, M., Rychlewski, L. and Ostrowski, J. (2007) A common cis-element in promoters of protein synthesis and cell cycle genes. Acta Biochim Pol 54, 89-98.

Xie, K. (2001) Interleukin-8 and human cancer biology. Cytokine Growth Factor Rev 12, 37591. 
Xu, B., Doughman, Y., Turakhia, M., Jiang, W., Landsettle, C.E., Agani, F.H., Semenza, G.L., Watanabe, M. and Yang, Y.C. (2007) Partial rescue of defects in Cited2-deficient embryos by HIF-1alpha heterozygosity. Dev Biol 301, 130-40.

Yamazaki, S., Muta, T. and Takeshige, K. (2001) A novel IkappaB protein, IkappaB-zeta, induced by proinflammatory stimuli, negatively regulates nuclear factor-kappaB in the nuclei. J Biol Chem 276, 27657-62.

Yang, D., Chertov, O., Bykovskaia, S.N., Chen, Q., Buffo, M.J., Shogan, J., Anderson, M., Schroder, J.M., Wang, J.M., Howard, O.M. and Oppenheim, J.J. (1999) Betadefensins: linking innate and adaptive immunity through dendritic and $\mathrm{T}$ cell CCR6. Science 286, 525-8.

Yang, L., Cohn, L., Zhang, D.H., Homer, R., Ray, A. and Ray, P. (1998) Essential role of nuclear factor kappaB in the induction of eosinophilia in allergic airway inflammation. J Exp Med 188, 1739-50.

Yoshimura, A., Wakabayashi, Y. and Mori, T. (2010) Cellular and molecular basis for the regulation of inflammation by TGF-beta. J Biochem 147, 781-92.

Yu, D., Tan, A.H., Hu, X., Athanasopoulos, V., Simpson, N., Silva, D.G., Hutloff, A., Giles, K.M., Leedman, P.J., Lam, K.P., Goodnow, C.C. and Vinuesa, C.G. (2007) Roquin represses autoimmunity by limiting inducible T-cell co-stimulator messenger RNA. Nature 450, 299-303.

Yu, E.Z., Li, Y.Y., Liu, X.H., Kagan, E. and McCarron, R.M. (2004) Antiapoptotic action of hypoxia-inducible factor-1 alpha in human endothelial cells. Lab Invest 84, 553-61.

Yuan, X., Naguib, S. and Wu, Z. (2011) Recent advances of siRNA delivery by nanoparticles. Expert opinion on drug delivery 8, 521-36.

Zetterberg, H., Blennow, K. and Hanse, E. (2010) Amyloid beta and APP as biomarkers for Alzheimer's disease. Exp Gerontol 45, 23-9.

Zhang, C. and Wong-Riley, M.T. (2000) Depolarizing stimulation upregulates GA-binding protein in neurons: a transcription factor involved in the bigenomic expression of cytochrome oxidase subunits. Eur J Neurosci 12, 1013-23.

Zhang, J.Z., Sinha, M., Luxon, B.A. and Yu, X.J. (2004) Survival strategy of obligately intracellular Ehrlichia chaffeensis: novel modulation of immune response and host cell cycles. Infect Immun 72, 498-507.

Zhang, X., Jin, J., Peng, X., Ramgolam, V.S. and Markovic-Plese, S. (2008) Simvastatin inhibits IL-17 secretion by targeting multiple IL-17-regulatory cytokines and by inhibiting the expression of IL-17 transcription factor RORC in $\mathrm{CD} 4^{+}$lymphocytes. J Immunol 180, 6988-96.

Zhang, X.R., Zhang, L.Y., Devadas, S., Li, L., Keegan, A.D. and Shi, Y.F. (2003) Reciprocal expression of TRAIL and CD95L in Th1 and Th2 cells: role of apoptosis in T helper subset differentiation. Cell Death Differ 10, 203-10.

Zhang, Y., Zhang, J., Tian, C., Xiao, Y., He, C., Li, X., Boqati, A., Huang, J., Fan, H. (2010) The $-308 \mathrm{G} / \mathrm{A}$ polymorphism in TNF-a gene is associated with asthma risk: an update by meta analysis. J Clin Immunol 31, 174-85.

Zhao, L., Furebring, M., Xu, S. and Venge, P. (2004) Subcellular localization and mobilization of carcinoembryonic antigen-related cell adhesion molecule 8 in human neutrophils. Br J Haematol 125, 666-73. 
Zheng, Y., Josefowicz, S.Z., Kas, A., Chu, T.T., Gavin, M.A. and Rudensky, A.Y. (2007) Genome-wide analysis of Foxp3 target genes in developing and mature regulatory T cells. Nature 445, 936-40.

Zhou, S., Ou, R., Huang, L. and Moskophidis, D. (2002) Critical role for perforin-, Fas/FasL-, and TNFR1-mediated cytotoxic pathways in down-regulation of antigen-specific $\mathrm{T}$ cells during persistent viral infection. J Virol 76, 829-40.

Zou, Y.R., Kottmann, A.H., Kuroda, M., Taniuchi, I. and Littman, D.R. (1998) Function of the chemokine receptor CXCR4 in haematopoiesis and in cerebellar development. Nature 393, 595-9.

Zylbersztejn, K. and Galli, T. (2011) Vesicular traffic in cell navigation. FEBS J. 


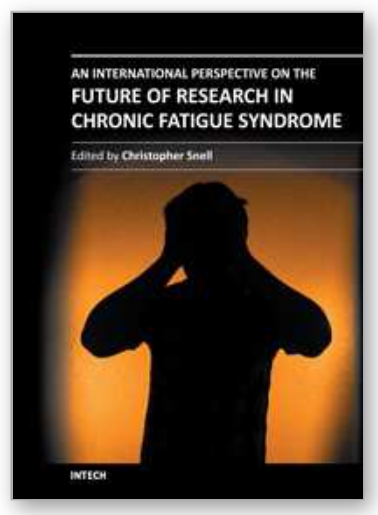

\author{
An International Perspective on the Future of Research in Chronic \\ Fatigue Syndrome \\ Edited by Dr. Christopher R. Snell
}

ISBN 978-953-51-0072-0

Hard cover, 104 pages

Publisher InTech

Published online 15, February, 2012

Published in print edition February, 2012

While the chapters in this book are a long way from solving the enigma that is CFS, they do represent important attempts to understand this complex and perplexing disease. A common theme in them all is CFS as a multisystem disease with the possibility of more than one cause and influenced by a variety of interacting factors. Further, they acknowledge the reality of CFS for persons with this disease and the importance of finding causes, treatments and ultimately a cure. As advanced biomedical research techniques are increasingly applied to the study of CFS, it is surely only a matter of time before biomarkers are identified, etiologies understood, and remedies devised.

\title{
How to reference
}

In order to correctly reference this scholarly work, feel free to copy and paste the following:

Ekua W. Brenu, Kevin J. Ashton, Gunn M. Atkinson, Donald R. Staines and Sonya Marshall-Gradisnik (2012). Gene Expression in Chronic Fatigue Syndrome, An International Perspective on the Future of Research in Chronic Fatigue Syndrome, Dr. Christopher R. Snell (Ed.), ISBN: 978-953-51-0072-0, InTech, Available from: http://www.intechopen.com/books/an-international-perspective-on-the-future-of-research-in-chronic-fatiguesyndrome/gene-expression-in-chronic-fatigue-syndrome

\section{INTECH}

open science | open minds

\section{InTech Europe}

University Campus STeP Ri

Slavka Krautzeka 83/A

51000 Rijeka, Croatia

Phone: +385 (51) 770447

Fax: +385 (51) 686166

www.intechopen.com

\section{InTech China}

Unit 405, Office Block, Hotel Equatorial Shanghai

No.65, Yan An Road (West), Shanghai, 200040, China

中国上海市延安西路65号上海国际贵都大饭店办公楼 405 单元

Phone: +86-21-62489820

Fax: +86-21-62489821 
(C) 2012 The Author(s). Licensee IntechOpen. This is an open access article distributed under the terms of the Creative Commons Attribution 3.0 License, which permits unrestricted use, distribution, and reproduction in any medium, provided the original work is properly cited. 